\title{
Size, age composition, and upstream migration of American eels at the Millville Dam eel ladder, Shenandoah River, West Virginia
}

Heather Hildebrand

West Virginia University

Follow this and additional works at: https://researchrepository.wvu.edu/etd

\section{Recommended Citation}

Hildebrand, Heather, "Size, age composition, and upstream migration of American eels at the Millville Dam eel ladder, Shenandoah River, West Virginia" (2005). Graduate Theses, Dissertations, and Problem Reports. 2217.

https://researchrepository.wvu.edu/etd/2217

This Thesis is protected by copyright and/or related rights. It has been brought to you by the The Research Repository @ WVU with permission from the rights-holder(s). You are free to use this Thesis in any way that is permitted by the copyright and related rights legislation that applies to your use. For other uses you must obtain permission from the rights-holder(s) directly, unless additional rights are indicated by a Creative Commons license in the record and/ or on the work itself. This Thesis has been accepted for inclusion in WVU Graduate Theses, Dissertations, and Problem Reports collection by an authorized administrator of The Research Repository @ WVU. For more information, please contact researchrepository@mail.wvu.edu. 
Size, age composition, and upstream migration of American eels at the Millville Dam eel ladder, Shenandoah River, West Virginia

\author{
Heather Hildebrand
}

Thesis submitted to the Davis College of Agriculture, Forestry, and Consumer Sciences at West Virginia University in partial fulfillment of the requirements

for the degree of

Master of Science

in

Wildlife and Fisheries Resources

\author{
Stuart A. Welsh, Ph.D., Chair \\ Patricia Mazik, Ph.D. \\ Kyle J. Hartman, Ph.D. \\ Kerry Bledsoe, M.S.
}

Division of Forestry

Morgantown, WV

2005

Keywords: American eel (Anguilla rostrata), environmental variables, upstream movement, yellow-phase, hydroelectric dams, Shenandoah River 


\section{ABSTRACT}

Size, age composition, and upstream migration of American eels at the Millville Dam eel ladder, Shenandoah River, West Virginia

\section{Heather Hildebrand}

Abundances of American eel (Anguilla rostrata) are declining along the east coast of the United States and Canada, possibly due to habitat loss and barriers to migration. In Atlantic coast watersheds, dams detain upstream migration of juveniles, and little is known about age class composition, age-length relationships, or environmental cues to upstream migration of yellow-phase eels. An eel ladder was installed on the Millville hydroelectric dam, lower Shenandoah River, WV, to facilitate and monitor the upstream movement of yellow phase eels. Daily length measurements (TL cm) and weights ( $\mathrm{g}$ ) were taken on eels using the ladder during three sampling periods; spring/summer 2004 (May 14 July 23), fall 2004 (Sept 10 - 30), and spring/summer 2005 (June 1 - July 31). Additionally, otolith-based ages were estimated from a subsample of eels. To examine environmental variables associated with upstream migration, candidate models were fit to daily count data and included combinations of four environmental covariates (barometric pressure, local precipitation, lunar illumination, and river flow) and a year effect. A total of 4,847 eels used the ladder during the three sampling periods. Eel sizes were similar among sampling periods (range 19 - $75 \mathrm{~cm} \mathrm{TL}$ ), and age estimates from 74 eels ( 21.4 - $55 \mathrm{~cm} \mathrm{TL}$ ) ranged from 3 to 10 years. Estimates of mean length at age of eels from Shenandoah River were low relative to published estimates from southern and northern latitudes. Peaks in eel counts coincided primarily with low levels of lunar illumination or with rise in river flow, and the data supported an additive model of lunar illumination and river flow. The data did not support singlevariable or additive models with covariates of barometric pressure or local precipitation, or models with a year effect. Management strategies for American eels will benefit from short and long-term studies of eel ladders, including additional focus on eel counts, size and age composition, and upstream migration. 


\section{DEDICATION}

To Zach, thank you for listening and laughing with me when I needed it. 


\section{ACKNOWLEDGEMENTS}

I would like to extend thanks to my graduate committee, especially Dr. Stuart Welsh for his guidance, Kerry Bledsoe, Dr. Kyle Hartman, and Dr. Pat Mazik, for their contributions both to this project and my various learning experiences throughout the past two years.

Funding was provided through EPRI (Electric Power Research Institute), Allegheny Energy (AE), the West Virginia Cooperative Fish and Wildlife Research Unit of the United States Geological Survey, and West Virginia Division of Natural Resources. I

thank Dr. Doug Dixon (EPRI), Chuck Simons (AE), and David Sutherland (U.S. Fish and Wildlife Service) for their contributions to this project.

Special thanks and appreciations to Gary Harbaugh and the crew at the Millville hydroelectric facility, Missy Gamber, Ryan Braham and Allie, Liz Osier, Chris Horn, Ryan Utz, Ken Sheehan, and Ben Lenz for their assistance with field work and data collection.

A special thanks to Ken Oliveira as well for his time in teaching me otolith aging techniques.

Thank you Becky Nestor for always being there when the students need you.

A final thanks to my parents for always believing in me and helping me to believe in myself. 


\section{TABLE OF CONTENTS}

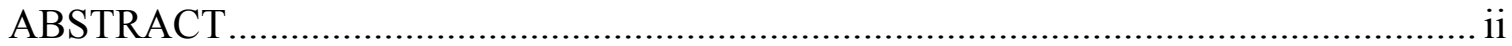

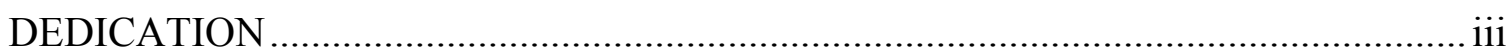

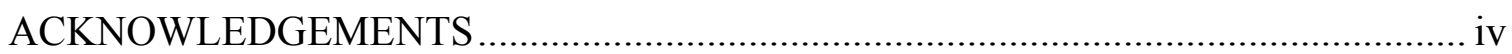

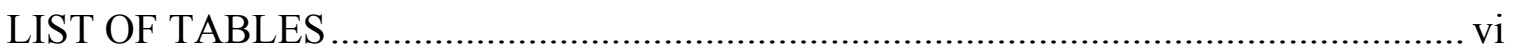

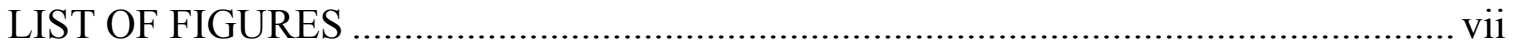

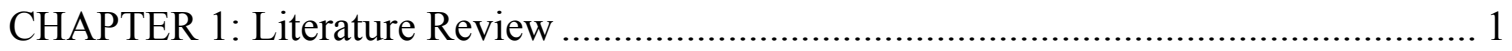

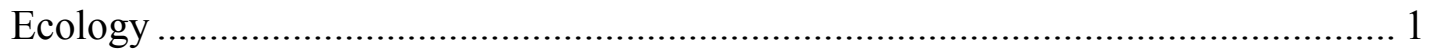

Environmental Cues to Upstream Migration ......................................................... 3

Migration Concerns .......................................................................................... 4

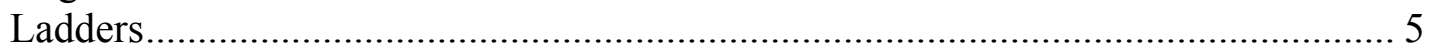

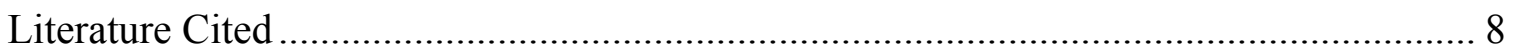

CHAPTER 2: Environmental variables associated with upstream migration and length and age of American eels at the Millville Dam eel ladder, Shenandoah River, West Virginia. 23

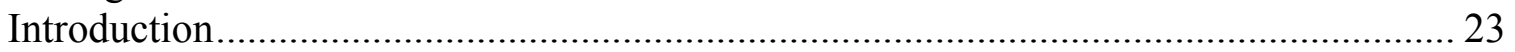

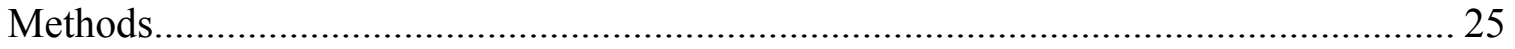

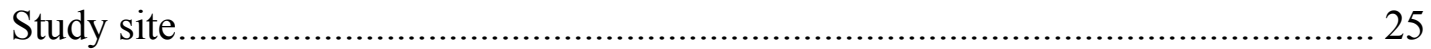

Ladder Design and Placement ......................................................................... 26

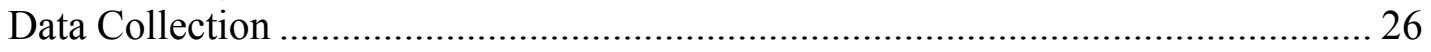

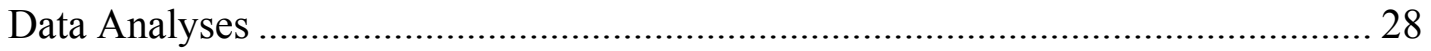

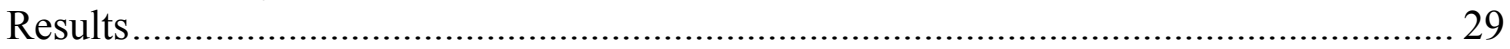

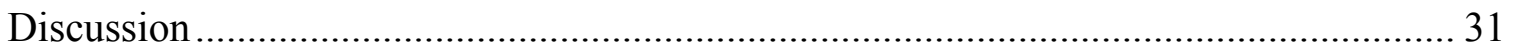

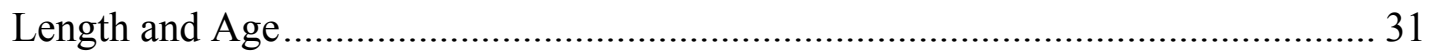

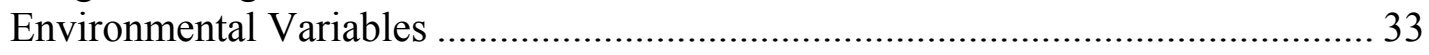

Implications for management and research ......................................................... 34

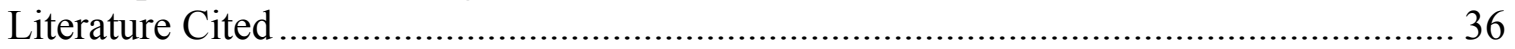

APPENDIX 


\section{LIST OF TABLES}

Table 1. List of models with corresponding hypotheses. Each of the 11 models was repeated with a year effect for a total set of 22 candidate models

Table 2. Mean, standard error (SE), and range of environmental variables depicted for three sampling periods of a study of upstream migration of American eels at the Millville Dam eel ladder, Shenandoah River, West Virginia...

Table 3. Mean total length $(\mathrm{cm})$ at age of American eels from a latitudinal range of Atlantic slope drainages

Table 4. Model selection statistics, sample size (n), number of parameters $(K)$, log likelihood values, Akaike Information Criterion $\left(\mathrm{QAIC}_{\mathrm{c}}\right)$ values adjusted for small sample size and overdispersion, distance from lowest QAIC ${ }_{\mathrm{c}}\left(\Delta_{i}\right)$, and Akaike weights $\left(\mathrm{w}_{i}\right)$ from a set of 22 candidate models. Variables include a year effect (year) and environmental covariates: lunar illumination (lunar), river flow (flow), local precipitation (precip), and barometric pressure (bp) 


\section{LIST OF FIGURES}

Figure 1. Length frequency histogram of eels collected from the Millville

Dam eel ladder during (A) Aug 28-Sept 17, 2003, (B) May 14-July

23, 2004, (C) Sept 10-30, 2004, and (D) June 1-July 31, 2005.

Figure 2. The length-weight relationship of eels $(\mathrm{N}=4,847)$ pooled from three sampling periods at the Millville Dam eel ladder, Shenandoah River, West Virginia........................................................ 50

Figure 3. Age-length (A) and age-weight (B) relationships of American eels from the Millville Dam eel ladder, Shenandoah River, West Virginia

Figure 4. Daily counts of eels at the Millville Dam eel ladder and associated environmental variables (lunar illumination and river flow) during two sampling periods; (A) May 14-July 23, 2004 and (B) June 1-July 31, 2005. 


\section{CHAPTER 1: Literature Review}

This thesis includes two chapters; a literature review of American eels (Anguilla rostrata) and a manuscript from a study of yellow-phase American eels at the Millville Dam eel ladder, lower Shenandoah River, West Virginia. In the first chapter, I review the literature of American eel ecology, cues to upstream eel migration, and dam related influences on eel movements. A manuscript (Chapter 2) documents numbers of eels, age/length of eels, and environmental variables associated with upstream eel movements at the Millville Dam eel ladder.

\section{Ecology}

The American eel (Anguilla rostrata), a catadromous fish distributed widely as a panmictic population from Greenland to Venezuela (Barbin and McCleave 1997, Krueger and Oliveira 1999, and Oliveira 1999), develops into five life stages: leptocephalus, glass, elver, yellow, and silver eel. American eels spawn in late winter-early spring in the Sargasso Sea (Tsukamoto and Aoyama 1998, Oliveira 1999, Powles and Warlen 2002). Leptocephali (7-10 mm TL) drift in the upper $300 \mathrm{~m}$ of the water column (Kleckner et al. 1983) and transform into glass eels during transport northwest along the east coast of the United States (Helfman et al. 1987, Dutil et al. 1989, Haro and Krueger 1990). The elver stage occurs in estuaries and is characterized by an elongate shape and long-based dorsal and anal fins merging with the caudal (Able and Fahay 1998, Powles and Warlen 2002). Elvers adjust physiologically to freshwater during upstream migration from tidal to nontidal habitats (Haro and Krueger 1988, Dutil et al. 1989). Eels are characterized as yellow phase once complete pigmentation has occurred and after TL exceeds (approximately) 100mm (Able and Fahay 1998, ASMFC 1999, BEAK 2001). The yellow phase (a feeding and growth phase) is the transition before the sexually-mature 
silver phase (Able and Fahay 1998, Oliveira 1999, BEAK 2001), and can last 9 to 30 years for females and 7 to 12 years for males (Helfman et al. 1987, Able and Fahay 1998, Cottrill et al. 2002, Goodwin and Angermeier 2003).

Most somatic growth occurs in the yellow phase and gender differences are evident. Females grow larger in the more northern regions of their freshwater distribution (Ford and Mercer 1986, Barbin and McCleave 1997), while males tend to occur in brackish water (Helfman et al. 1987, Wang and Tzeng 1998, Goodwin and Angermeier 2003) and exhibit lower growth rates compared to the females (Helfman et al. 1984, Oliveira 1997, Powles and Warlen 2002). Growth rates of males and females diverged at age 4; however, they did not become statistically different until age 6 (Helfman et al. 1984, Oliveira and McCleave 2002). Male eels begin metamorphosis into the silver phase at smaller sizes $(<400 \mathrm{~mm})$ and younger ages, which suggests that they switch resources away from somatic growth to gonadal development earlier (Krueger and Oliveira 1997, Krueger and Oliveira 1999, Oliveira and McCleave 2002). This explains the sharper decline in male growth after age 3 (Helfman et al. 1984, Oliveira 1997, Oliveira and McCleave 2000).

At maturity both sexes undergo a fall migration downstream to the sea (Barbin and McCleave 1997, Able and Fahay 1998, Krueger and Oliveira 1999). Metamorphosis to a silver eel stage accompanies this migration; during which the eye diameter enlarges (ASMFC 1999, Cottrill et al. 2002), the internal organs atrophy, and the lateral surface assumes a silver sheen (Hain 1975, Winn and Winn 1975, Krueger and Oliveira 1999). Movement within the ocean to the Sargasso Sea is not well understood. After spawning, adults are presumed to die (Able and Fahay 1998, Krueger and Oliveira 1999, Tsukamoto et al. 2002). 


\section{Environmental Cues to Upstream Migration}

Although the majority of the eel's life is spent in the yellow phase and in freshwater systems, little is known about environmental influences on movement and upstream migration. Environmental cues initiating migration are difficult to ascertain with respect to yellow phase eels (Barbin 1998) due to collection techniques of juveniles at the interface of a stream and an estuary (Sorensen et al. 1986, McCleave and Wipplehauser 1987). Decreasing abundance with increased distance from the ocean, contributes to the difficulty in assessing the impacts of environmental variables on upstream migration (Wiley et al. 2004, Laffaille et al. 2005). Most data of environmental influences on upstream migration are from estuaries, the interface of estuaries and freshwater, and tidally-influenced freshwaters (Martin 1995, White and Knights 1997, Laffaille et al. 2003).

Water chemistry, sunlight, barometric pressure, air temperature, and water temperature potentially cue upstream migration of eels in freshwaters (Walsh et al. 1983, Parker and McCleave 1997, Wippelhauser and McCleave 1988). Although Miles (1968) found an association with water $\mathrm{pH}$ and movement of elvers, Sorensen (1984) was unable to verify this finding. Sunlight, barometric pressure, air and water temperature correlated positively with the onset of upstream migration (Sorensen and Bianchini 1986, Baras et al. 1998, Euston et al. 1998). Upstream migration coincided with water temperatures from $12^{\circ} \mathrm{C}$ to $19^{\circ} \mathrm{C}$ in a Rhode Island brook (Sorensen and Bianchini 1986) with peak migration around $20^{\circ} \mathrm{C}$ in the rivers Severn and Avon in England (White and Knights 1997), which was lower than the $20-25^{\circ} \mathrm{C}$ peak range reported by Verdon and Desrochers in the St. Lawrence River in Canada (2003). Water temperatures exceeding this 
threshold $\left(20^{\circ} \mathrm{C}\right)$ at the estuarine-riverine interface had little (if any) influence on movements (Sorensen et al. 1986, Haro and Krueger 1988, Haro and Krueger 1991). However, Sorensen and Bianchini (1986) stated that their study failed to discern any environmental variable with a strong influence of upstream migration of elvers in freshwater systems.

Olfactory, river flow, and lunar phase potentially cue upstream migration of yellow phase eels. Olfactory cues are likely important, although the odorant is unidentified (Sorensen 1986, McCleave and Wippelhauser 1987, Barbin 1998). Sorensen (1984) found streambed gravel and stones, dead alewife (Alosa pseudoharengus) eggs, leaf detritus, and riverbank mud to be possible chemoattractants. River flow and lunar phase coincide with yellow-phase movements (Durif et al. 2003, Hammond 2003). Eel activity increases nocturnally with peak activity around midnight (Dutil et al. 1987, 1988, Parker 1995), often beginning with the waning third quarter moon (Lamothe et al. 2000, Hain 1975).

\section{Migration Concerns}

The abundance of American eel (based on catch data) has declined dramatically over the past two decades from $816,466 \mathrm{~kg}$ in 1985 to $294,881 \mathrm{~kg}$ in 2002 along the east coast of the United States (ASMFC 2004). Researchers speculate population declines are due to habitat loss (Wiley 1999, Casselman 2003, Tremblay 2005), over harvest (Appelbaum et al. 1998, Haro et al. 2000, Patrick et al. 2000, Casselman 2003), pollution and/or barriers to migration (Wiley 1999, Neraas and Spruell 2001, Wiley et al. 2004). The recent awareness of population fluctuations caused the Atlantic States Marine Fisheries Commission to draft an eel management plan (Euston et al. 1998, ASMFC 1999, Patrick et al. 2000). The management plan recommends research of both up and downstream eel 
passage at hydroelectric dams (ASMFC 1999, Patrick et al. 2000). However, more than $90 \%$ of dams on the eastern seaboard are not hydroelectric facilities, and are therefore not subject to continual re-licensing and fish passage analysis (ASMFC 1999, FERC 2003). Not all dams impede eel movements; however, few studies have examined the magnitude of impacts of dams or management practices associated with dams (Goodwin et al. 1999, ASMFC 1999).

Habitat fragmentation by dams, navigation weirs and hydroelectric plants have reduced ranges and increased extinction risks of numerous migratory fishes (Agostinho et al. 2002, Ovidio and Philippart 2002). Dams screen and reduce abundances of eels in upper watersheds (Wells 1999, McCleave 2001, Goodwin and Angermeier 2003). Turbine mortality for downstream migrants can exceed 25\% (EPRI 1999) with some estimates exceeding 50\% (Ritter et al. 1997, Verreault and Dumont 2000). In the St. Lawrence River watershed, a total of 8,411 dams (at least $2.5 \mathrm{~m}$ high) prevent, hinder, or delay access to $12,140 \mathrm{~km}^{2}$ of freshwater habitat (10 m or less deep)(Verreault et al. 2004). Based on data analysis from three tributaries in the St. Lawrence River watershed and historic distributions, annual productivity loss was estimated at 836,500 eels (Verreault et al. 2004). Based on historical recruitment, re-opening access upstream of dams to migrant yellow eels could potentially contribute 737,000 spawners a year (Verreault et al. 2004).

\section{Ladders}

Structures and mechanisms such as ladders, elevators and floodgates are constructed worldwide to transport fishes up and downstream of dams (Cada 2001, Agostinho et al. 2002, FERC 2004). Upstream passage technologies are well developed for certain anadromous species, mainly salmonids and clupeids, in North America and Europe 
(Larinier 2000). Passes for young eels are used in Europe, Canada, the United States and New Zealand (Larinier 2000, Verdon et al. 2003, FERC 2004).

Eel ladder monitoring provides information about upstream migration and recruitment of yellow phase eels. Based on an eel ladder study at Arzal dam (Vilaine, France), eel odor (from conspecifics on the ladder) increased eel use of the ladder (Briand et al. 2002). The mean catch of glass and yellow eel was about 1.4 times higher with the presence of conspecific odor (Briand et al. 2002). Possible sources of attraction are the skin, mucus, bile salts, or other amino acids (Saglio 1982, Sorensen 1986, Briand et al. 2002). Briand et al. (2002) concluded that odor assists migrant eels in location of passes, and eel ladder designs would benefit from water diversion from holding bins.

Passage of juveniles decreased (118-fold ) at the eel ladder of the R.H. Saunders hydroelectric dam at Cornwall, Ontario from 1982-1983 and has progressively declined since the mid 1980's (Casselman et al. 1997, McGrath et al. 2003). At this ladder, larger eels pre-dominated initial migrations with smaller eels being more abundant during peak migration, but decreasing in number as the season progressed and water temperatures decreased (Liew 1978, McGrath et al. 2003). Before ladder installation, eels remained downstream and grew in size, as a result, the first two years of ladder operation yielded larger eels with a gradual decrease in eel size by the third and fourth years (Liew 1978, McGrath et al. 2003). The primarily nocturnal use of this ladder corroborates findings of studies on the Richelieu River and a tidal tributary of the St. Lawrence River (McGrath et al. 2003).

A study of the upstream movement of yellow phase eels between the Beauharnois (Quebec) and the Moses-Saunders (Ontario/New York) hydroelectric dams on the St. Lawrence River investigated both the movement between the two dams and the effects of 
commercial harvest on eel movements (Verdon and Desrochers 2003). Peak migration occurred between 16 July and 15 August, corresponding with temperatures above $20^{\circ} \mathrm{C}$, which agreed with other studies on the Sud-Ouest and Rimouski rivers (two tributaries of the lower St. Lawrence River) (Verdon and Desrochers 2003). The number of eels from the Moses-Saunders to the Beauharnois dam was reduced, possibly due to the presence of the locks on both dams having a compounding effect on the upstream movement of eels (Verdon and Desrochers 2003).

In 1997, an eel ladder was installed at the Chambly dam on the Richelieu River (115 $\mathrm{km}$ between Lake Champlain and the St. Lawrence River) for the purpose of monitoring upstream migration of yellow phase eels (Verdon et al. 2003). Results of movement and water temperature agreed with past research, where the onset of upstream migration in the Richelieu River occurred about a month earlier than in the upper St. Lawrence (Verdon et al. 2003). Further, yellow eels were active nocturnally, and migrations peaked between 18:00 and 24:00 hours, and were disrupted by artificial light (Verreault 1995, Verdon et al. 2003). Eels released at the dam base (on both banks) were recaptured in equal proportion in the ladder; a finding that supports active eel movements along the dam (McGrath et al. 2003,Verdon et al. 2003). Knights and White (1998) found European eels in quieter water near the bottom and sidewalls of a dam, and suggested the entrance location to eel passes should be located near the base of walls. Knights and White (1998) also concluded that strong flows near ladder entrances attract eels, a finding consistent with observations at the Chambly Dam (Verdon et al. 2003).

An eight year study on the Fremur River, France, examined temporal changes in density, biomass, and length of eels following construction of eel passes (Laffaille et al. 2005). The Fremur, a small river of northern Brittany (France), represents many small 
coastal catchments in the Biscay region. Barriers on the Fremur, however, have disturbed natural connectivity, including three high dams $(14 \mathrm{~m})$ that inhibit eel upstream migration and reduce recruitment of elvers and yellow eels (Laffaille et al. 2005). No significant decreases in eel densities were observed in the Fremur river, except in the most upstream part of the catchment, despite a general decline elsewhere in Europe. The presence of eels before the installation of the passes suggests elvers could bypass the dams, however, passes greatly improve access to upstream habitat and are indispensable for assisting upstream movements of larger eels (>120mm) (Laffaille et al. 2005). During 1997-2003 following eel pass installation, over 100,000 eels were counted from passes on the Fremur River.

Given apparent declines in American eel abundance over portions of the species' range, knowledge of freshwater migration may be increasingly important for effective management and conservation (Oliveira and McCleave 2000, Wiley et al. 2004). Eel ladders provide an opportunity for study of freshwater migration, and increase access to upper watersheds.

\section{Literature Cited}

Able, K.W., and M.P Fahay. 1998. The first year in the life of estuarine fishes in the middle Atlantic bight. Rutgers University Press, Livingston Campus, New Brunswick, New Jersey. Pages 38-41.

Agostinho, A.A, L.C. Gomes, D.R. Fernandez, and H.I. Suzuki. 2002. Efficiency of fish ladders for neotropical ichthyofauna. River Research and Applications 18: 299306.

Appelbaum, S., A. Chernitsky, and V. Birkan. 1998. Growth observations on European 
(Anguilla anguilla) and American (Anguilla rostrata) glass eels. The Bengis Centre for Desert Aquaculture, Ben-Gurion University of the Negev, Israel.

Arai, T., T. Otake, and K. Tsukamoto. 2000. Timing of metamorphosis and larval segregation of the Atlantic eels Anguilla rostrata and A.anguilla, as revealed by otolith microstructure and microchemistry. Marine Biology 137: 39-45.

Atlantic States Marine Fisheries Commission (ASMFC). 1999. Interstate Fishery management plan for American eel. ASMFC Fishery Management Report No. 36, Washington, D.C.

Atlantic States Marine Fisheries Commission (ASMFC). 2004. Review of the Atlantic States Marine Fisheries Commission Management plan for American eel. Washington, D.C.

Baras, E., D. Jeandrain, B. Serouge, and J.C. Philippart. 1998. Seasonal variations in time and space utilization by radio-tagged yellow eels Anguilla anguilla in a small stream. Hydrobiologia 371/372: 187-198.

Barbin, G.P., and J.D. McCleave. 1997. Fecundity of the American eel Anguilla rostrata at $45^{\circ} \mathrm{N}$ in Maine, U.S.A. Journal of Fish Biology 51: 840-847.

Barbin, G. 1998. The role of olfaction in homing and estuarine migratory behavior of yellow-phase American eels. The Canadian Journal of Fisheries Aquatic Sciences 55: 564-575.

BEAK International Inc. 2001. The decline of the American eel Anguilla rostrata in the Lake Ontario/St. Lawrence River ecosystem: A modeling approach to identification of data gaps and research priorities. Lake Ontario Committee: Great Lakes Fishery Commisson Ann Arbor, Michigan. Pgs. 1-70.

Boubee, J., B. Chisnall, E. Watene, and E. Williams. 2003. Enhancement and 
management of eel fisheries affected by hydroelectric dams in New Zealand. In D.A. Dixon (ed) Biology, Management, and Protection of Catadromous Eels. Bethesda, MD, USA: American Fisheries Society, Symposium 33 pp. 191-206. Bozeman, E.L., G.S. Helfman, and T. Richardson. 1985. Population size and home range of American eels in a Georgia tidal creek. Transactions of the American Fisheries Society 114: 821-825.

Briand, C., D. Fatin, and A. Legault. 2002. Role of eel odor on the efficiency of an eel, Anguilla anguilla, ladder and trap. Environmental Biology of Fishes 65: 473-477.

Broad, T.L., C.R. Townsend, C.J. Arbuckle, and D.J. Jellyman. 2001. A model to predict the presence of longfin eels in some New Zealand streams, with particular reference to riparian vegetation and elevation. Journal of Fish Biology 58: 10981112.

Burnham, K.P. and D.R. Anderson. 2003. Model selection and multi-model inference: a practical information-theoretic approach, Second Edition. Springer, New York, New York.

Cada, G.F. 2001. The development of advanced hydroelectric turbines to improve fish passage survival. Fisheries 26(9): 14-23.

Casselman, J.M. 2003. Dynamics of resources of the American eel, Anguilla rostrata: declining abundance in the 1990s. Eel Biology, Springer-Verlag Tokyo, Japan. Pgs. 255-274.

Castonguay, M., P.V. Hudson, C.M. Couillard, M.J. Eckersley, J.D. Dutil, and G. Verreault. 1994. Why is recruitment of the American eel, Anguilla rostrata, declining in the St. Lawrence River and Gulf? Canadian Journal of Fisheries and Aquatic Sciences 51: 479-488. 
Cottrill, A. R., S.R. McKinley, and G. Van Der Kraak. 2002. An examination of utilizing external measures to identify sexually maturing female American eels, Anguilla rostrata, in the St. Lawrence River. Environmental Biology of Fishes 65: 271287.

Coutant, C.C., and R.R. Whitney. 2000. Fish behavior in relation to passage through hydropower turbines : A review. Transactions of the American Fisheries Society 129: $351-380$.

Denoncourt, C. E., and J.R. Stauffer, Jr. 1992. Feeding selectivity of the American eel Anguilla rostrata in the upper Delaware River. American Midland Naturalist 129: 301-308.

Durif, C., P. Elie, C. Gosset, J. Rives, and F. Travade. 2003. Behavioral study of downstream migrating eels by radio telemetry at a small hydroelectric power plant. In D.A. Dixon (ed). Biology, Management, and Protection of Catadromous Eels. Bethesda, MD, USA: American Fisheries Society, Symposium 33 pp. 343356.

Dutil, J. -D., M. Besner, and S.D. McCormick. 1987. Osmoregulatory and ionoregulatory changes and associated mortalities during the transition of maturing American eels to a marine environment. American Fisheries Society Symposium 1: 175-190.

Dutil, J.-D., A. Giroux, A. Kemp, G. Lavoie, and J.P. Dallaire. 1988. Tidal influence on movements and on daily cycle of activity of American eels. Transactions of the American Fisheries Society 117: 488-494.

Dutil, J.-D., M. Michaud, and A. Giroux. 1989. Seasonal and diel patterns of stream invasion by American eels (Anguilla rostrata) in the northern Gulf of St. 
Lawrence. Canadian Journal of Zoology 67: 182-188.

Eales, J.G. 1968. The eel fisheries of eastern Canada. Bull. 166, Fisheries Resources Board of Canada $79 \mathrm{p}$.

Ege,V. 1939. A revision of the genus Anguilla shaw, a systematic, phylogenetic and geographical study. Dana 16: 1-256.

Euston, E. T., D. D. Royer, and C. L. Simons. 1997. Relationship of emigration of silver American eels (Anguilla rostrata) to environmental variables at a low head hydro station. Proceedings of the International Conference on Hydropower 1997:549558.

Euston, T. E., D.D. Royer, and C.L. Simons. 1998. American eels and hydro plants: clues to eel passage. Hydro Review 94-103.

Facey, D.E., and G. W. LaBar. 1981. Biology of American eels in Lake Champlain, Vermont. Transactions of the American Fisheries Society 110:396-402.

Federal Energy Regulatory Commission (FERC). 2003. Evaluation of mitigation effectiveness at hydropower projects: fish passage, draft report. Division of Hydropower Administration and Compliance Office of Energy Projects Federal Energy Regulatory Commission. September. Pgs. 1-64.

Federal Energy Regulatory Commission (FERC). 2004. Evaluation of mitigation effectiveness at hydropower projects: fish passage. Division of Hydropower Administration and Compliance. Office of Energy Projects. Federal Energy Regulatory Commission. September 2004.

Ford, T.E., and E. Mercer. 1986. Density, size distribution and home range of American eels, Anguilla rostrata, in a Massachusetts salt marsh. Environmental Biology of Fishes 17, no. 4: 309-314. 
Goodwin, K.R. 1999. American eel subpopulation characteristics in the Potomac River Drainage, Virginia. MS thesis. Virginia Polytechnic Institute, Blacksburg, VA.

Goodwin, K. R., P.L. Angermeier, and D.J. Orth. 1999. Final report: Assessing impacts of hydropower dams on upstream migration of American eel. Report submitted to the Virginia Department of Game and Inland Fisheries Richmond, VA.

Goodwin, K. R., and P.L. Angermeier. 2003. Demographic characteristics of American eel in the Potomac River drainage, Virginia. Transactions of the American Fisheries Society 132:524-535.

Gunning, G., and R.C. Shoop. 1962. Restricted movements of the American eel, Anguilla rostrata in freshwater streams, with comments on growth rate. Tulane Study of Zoology.9: 265-272.

Hain, J.H.W. 1975. The behavior of migratory eels, Anguilla rostrata, in response to current, salinity, and lunar period. Helgolander Meeresuntersuchungen 27: 211233.

Hammond, S. 2003. Seasonal movements of yellow-phase American eels (Anguilla rostrata) in the Shenandoah River, West Virginia. M.S. thesis. West Virginia University, Morgantown, West Virginia.

Haro, A.J., and W.H. Kreuger. 1988. Pigmentation, size, and migration of elvers (Anguilla rostrata) in a coastal Rhode Island stream. Canadian Journal of Zoology 66:2528-2533.

Haro, A. J., and W.H. Krueger. 1991. Pigmentation, otolith rings, and upstream migration of juvenile American eels (Anguilla rostrata) in a coastal Rhode Island stream. Canadian Journal of Zoology 69: 812-814.

Haro, A. J., W. Richkus, K. Whalen, A. Hoar, W. -D. Busch, S. Lary, T. Brush, and D. 
Dixon. 2000. Population decline of the American eel: implications for research and management. Fisheries 25(9): 7-16.

Haro, A., T. Castro-Santos, and J. Boubee. 2000. Behavior and passage of silver-phase American eels, Anguilla rostrata (LeSueur), at a small hydroelectric facility. Dana 12: 33-42.

Harrell, R.M., and H.A. Loyacano. 1976. Age, growth, and sex ratio of the American eel in the Cooper River, South Carolina. Proceedings of the Annual Conference of the Southeastern Association of Fish and Wildlife Agencies 34: 349-359.

Helfman, G.S., E.L. Bozeman, and E.B. Brothers. 1984. Size, age, and sex of American eels in a Georgia River. Transactions of the American Fisheries Society 113: 132141.

Helfman, G. S., D.E. Facey, H.L. Stanton, Jr., and E.L. Bozeman, Jr. 1987. Reproductive ecology of the American eel. American Fisheries Symposium 1: 42-56.

Helfman, G. S., and D.L. Winkelman. 1991. Energy trade-offs and foraging mode choice in American eels. Ecology 72(1): 310-318.

Hurley, D. A. 1972. The American eel (Anguilla rostrata) in eastern Lake Ontario. Journal of the Fisheries Research Board of Canada 29:535-543.

Jegstrup, I.M., and P. Rosenkilde. 2003. Regulation of post-larval development in the European eel: thyroid hormone level, progress of pigmentation and changes in behavior. Journal of Fish Biology 63: 168-175.

Jenkins, R. E., and N. M. Burkhead. 1994. Freshwater Fishes of Virginia, Bethesda, MD, USA: American Fisheries Society

Kleckner, R.C. and J.D. McCleave. 1982. Entry of migrating American eel leptocephali into the Gulf Stream system. Helgolander Meeresuntersuchungen 35: 329-339. 
Kleckner, R. C., J.D. McCleave, and G.S. Wippelhauser. 1983. Spawning of American eel, Anguilla rostrata, relative to thermal fronts in the Sargasso Sea. Environmental Biology of Fishes 9: 289-293.

Kleckner, R.C., and J.D. McCleave. 1985. Spatial and temporal distribution of American eel larvae in relation to North Atlantic Ocean current systems. Dana 4: 67-92.

Knights, B., and M. White. 1998. Enhancing immigration and recruitment of eels: the use of passes and associated trapping systems. Fisheries Management and Ecology 5: $459-471$.

Kraus, R.T., and D.H. Secor. 2003. Response of otolith Sr:Ca to a manipulated environment in young American eels. In D.A. Dixon (ed) Biology, Management, and Protection of Catadromous Eels. Bethesda, MD, USA American Fisheries Society, Symposium 33: pp. 79-85.

Krueger, W. H. and K. Oliveira. 1999. Evidence for environmental sex determination in the American eel, Anguilla rostrata. Environmental Biology of Fishes 55: 381389.

Krueger, W.H. and K. Oliveira. 1997. Sex, size, and gonad morphology of silver American eels Anguilla rostrata. Copeia (2) 415-420.

LaBar, G. W., and D.E. Facey. 1983. Local movements and inshore population sizes of American eels in Lake Champlain, Vermont. Transactions of the American Fisheries Society 112: 111-116.

Laffaille, P., E. Feunteun, A. Baisez, T. Robinet, A. Acou, A. Legault, and S. Lek. 2003. Spatial organisation of European eel Anguilla anguilla in a small catchment. Ecology of Freshwater Fish 12: 254-264.

Laffaille, P., A. Acou, J. Guillouet, and A. Legault. 2005. Temporal changes in European 
eel, Anguilla anguilla, stocks in a small catchment after installation of fish passes. Fisheries Management and Ecology 12: 123-129.

Lamothe, P.J., M. Gallagher, D.P. Chivers, and J.R. Moring. 2000. Homing and movement of yellow-phase American eels in freshwater ponds. Environmental Biology of Fishes 58: 393-399.

Larinier, M. 2000. Dams and fish migration. World Commission on Dams: Environmental Issues. Dams and Fish Migration Final Draft June 30.p 1-30.

Levesque, J.R. 1978. The effects of dams on American eel in the Thames River Watershed, Connecticut. M.S. thesis, University of Connecticut.

Levesque, J.R., and W.R. Whitworth. 1987. Age class distribution and size of American eel Anguilla rostrata in the Shetucket/Thames River, Connecticut. Journal of Freshwater Ecology 4: 17-22.

Liew, P.K.L. 1974-1978. Impact of the eel ladder on the upstream migrating eel (Anguilla rostrata) population in the St. Lawrence River at Cornwall. Ontario Ministry of Natural Resources Pgs 17-21.

Martin, M.H. 1995. The effects of temperature, river flow, and tidal cycles on the onset of glass eel and elver migration into fresh water in the American eel. Journal of Fish Biology 46: 891-902.

McCleave, J.D. 2001. Simulation of the impact of dams and fishing weirs on reproductive potential of silver-phase American eels in the Kennebec River Basin, Maine. North American Journal of Fisheries Management 21:592-605.

McCleave, J. D. and G.S. Wippelhauser. 1987. Behavioral aspects of selective tidal stream transport in juvenile American eels. American Fisheries Society Symposium 1: 138-150. 
McGrath, K.J., D. Desrochers, C. Fleury, and J.W. Dembeck. 2003. Studies of upstream migrant American eels at the Moses-Saunders Power Dam on the St. Lawrence River near Massena, New York. In D.A. Dixon (ed). Biology, Management, and Protection of Catadromous Eels. Bethesda, MD, USA. American Fisheries Society, Symposium 33: pp. 153-166.

Michaud, M., J.D. Dutil, and J.J. Dodson. 1988. Determination of the age of young eels, Anguilla rostrata, in freshwater, based on otolith surface area and microstructure. Journal of Fish Biology 32: 179-189.

Miles, S.G. 1968. Rheotaxis of elvers of the American eel (Anguilla rostrata) in the laboratory to water from different streams in Nova Scotia. Journal of Fisheries Resources Board of Canada 25(3) 1591-1602.

Moriarty, C. 1983. Age determination and growth rate of eels, Anguilla anguilla. The Journal of Fisheries Biology 23, 257-264.

Moriarty, C. and W. Dekker. 1997. Management of the European eel. Second Report of the EU Concerted Action AIR A94-1939. Fisheries Bulletin No. 15, Dublin: The Marine Institute, $110 \mathrm{pp}$.

Morrison, W.E. and D.H. Secor. 2003. Demographic attributes of yellow-phase American eels (Anguilla rostrata) in the Hudson River estuary. Canadian Journal of Fisheries Aquatic Sciences 60: 1487-1501.

Neraas, L. P., P. Spruell. 2001. Fragmentation of riverine systems: the genetic effects of dams on bull trout (Salvelinus confluentus) in the Clark Fork River System. Molecular Ecology 10: 1153-1164.

Oliveira, K. 1999. Life history characteristics and strategies of the American eel, Anguilla rostrata. Canadian Journal of Fisheries Aquatic Sciences 56:795-802. 
Oliveira, K. 1997. Movements and growth rates of yellow-phase American eels in the Annaquatucket River, Rhode Island. Transactions of the American Fisheries Society 126: 638-646.

Oliveira, K. 1996. Field validation of annular growth rings in the American eel, Anguilla rostrata, using tetracycline-marked otoliths. Fishery Bulletin 94: 186-189.

Oliveira, K., and J.D. McCleave. 2002. Sexually different growth histories of the American eel in four rivers in Maine. Transactions of the American Fisheries Society 131:203-211.

Oliveira, K., and J.D. McCleave. 2000. Variation in population and life history traits of the American eel, Anguilla rostrata, in four rivers in Maine. Environmental Biology of Fishes 59: 141-151.

Ovidio, M., J. Philippart. 2002. The impact of small physical obstacles on upstream movements of six species of fish. Hydrobiologia 483: 55-69.

Ozaki, Y., H. Okumura, Y. Kazeto, T. Ikeuchi, S. Ijiri, M. Nagae, S. Adachi, and K. Yamauchi. 2000. Developmental changes in pituitary-thyroid axis, and formation of gonads in leptochephali and glass eels of Anguilla sp. Fisheries Science 66: $1115-1122$.

Parker, S.J. 1995. Homing ability and home range of yellow-phase American eels in a tidally dominated estuary. Journal of Marine Biology Association U.K. 75: 127140.

Parker, S.J., and J.D. McCleave. 1997. Selective tidal stream transport by American eels during homing movements and estuarine migration. Journal of Marine Biology Association U.K. 77: 871-889.

Patrick, P.H., and R.S. McKinley. 1987. Field evaluation of a hidrostal pump for live 
transfer of American eels at a hydroelectric facility. North American Journal of Fisheries Management 7: 303-305.

Patrick, P. H., S.J. Poulton, and R. Brown. 2000. Using strobe lights and sound to protect American eels. Hydro Review 98-102.

Powles, P. M., and S.M. Warlen. 2001. Recruitment season, size, and age of young American eels (Anguilla rostrata) entering an estuary near Beaufort, North Carolina. Fisheries Bulletin 100: 299-306.

Ritter, J.A., M. Stanfield, and R.H. Peterson. 1997. Final Discussion, p. 170-172. In R.H. Peterson (ed) The American eel in eastern Canada: stock status and management strategies. Proceedings of eel management workshop, January 13-14, 1997, Quebec City, PQ. Canadian Technical Report of Fisheries and Aquatic Sciences 2196.

Russell, I.C., and E.C.E. Potter. 2003. Implications of the precautionary approach for the management of the European eel, Anguilla anguilla. Fisheries Management and Ecology 10: 395-401.

Secor, D.H., J.M. Dean, and E.H. Laban. 1992. Otolith removal and preparation for microstructural examination. In D.K. Stevenson and S.E. Compana (eds.), Otolith microstructure examination and analysis. Canadian Special Publications of Fisheries Aquatic Sciences 117: 119-127.

Sorensen, P.W., and M.L. Bianchini. 1986. Environmental correlates of freshwater migration of elvers of the American eel in a Rhode Island brook. Transactions of the American Fisheries Society 115: 258-268.

Sorensen, P.W. 1986. Origins of the freshwater attractant(s) of migrating elvers of the American eel, Anguilla rostrata. Environmental Biology of Fishes 17:185-200. 
Starkie, A. 2003. Management issues relating to the European eel, Anguilla anguilla. Fisheries Management and Ecology 10: 361-364.

Tesch, F. W. 1977. The eel. Biology and management of anguillid eels. Chapman and Hall, London.

Tsukamoto, K., J. Ayoyama, and J. Miller. 2002. Migration, speciation, and the evolution of diadromy in anguillid eels. Canadian Journal of Fisheries Aquatic Sciences 59: 1989-1998.

Tsukamoto, K., and J. Aoyama. 1998. Evolution of freshwater eels of the genus Anguilla: a probable scenario. Environmental Biology of Fishes 52: 139-148.

Tremblay, V. 2005. COSEWIC Status report on the American eel Anguilla rostrata prepared for the Committee on the Status of Endangered Wildlife in Canada by Valerie Tremblay on behalf of the Canadian Eel Science Working Group. May 2005. pgs. 1-43.

Tytell, E.D. 2004. The hydrodynamics of eel swimming II. Effect of Swimming Speed. Journal of Experimental Biology 207: 3265-3279.

Verdon, R., D. Desrochers. 2003. Upstream migratory movements of American eel Anguilla rostrata between the Beauharnois and Moses-Saunders Power Dams on the St. Lawrence River. In D.A. Dixon (ed). Biology, Management, and Protection of Catadromous Eels. Bethesda, MD. USA. American Fisheries Society, Symposium 33: pp.139-151.

Verdon, R., D. Desrochers, and P. Dumont. 2003. Recruitment of American eels in the Richelieu River and Lake Champlain: provision of upstream passage as a regional-scale solution to a large-scale problem. In D.A. Dixon (ed). Biology, Management, and Protection of Catadromous Eels. Bethesda, MD, 
USA: American Fisheries Society, Symposium 33. pp. 125-138

Verreault, G., P. Pettigrew, R. Tardif, and G. Pouliot. 1994. The exploitation of the migrating silver American eel in the St. Lawrence River estuary, Quebec, Canada. Biology, Management, and Protection of Catadromous Eels. In D.A. Dixon (ed). Biology, Management, and Protection of Catadromous Eels. Bethesda, MD, USA: American Fisheries Society, Symposium 33: 225-234.

Walsh, P.J., G.D. Foster, and T.W. Moon. 1983. The effects of temperature on metabolism of the American eel Anguilla rostrata compensation in the summer and torpor in the winter. Physiological Zoology 56: 532-540.

Wang, C.H., and W.N. Tzeng. 1998. Interpretation of geographic variation in size of American eel Anguilla rostrata elvers on the Atlantic coast of North America using their life history and otolith ageing. Marine Ecology Progress Series 168: $35-43$.

Watene, E.M., and J.A.T. Boubee. 2005. Selective opening of hydroelectric dam spillway gates for downstream migrant eels in New Zealand. Fisheries Management and Ecology 12: 69-75.

Wells, P.G. 1999. Environmental impacts of barriers on rivers entering the Bay of Fundy. Report of an ad hoc Environment Canada Working Group. Technical Report Series No. 334. Canadian Wildlife Service, Ottawa, ON. 43p.

White, E.M, and B. Knights. 1997. Dynamics of upstream migration of the European eel, Anguilla anguilla (L.), in the Rivers Severn and Avon, England, with special reference to the effects of man-made barriers. Fisheries Management and Ecology 4: $311-324$.

Wiley, D. 1999. The effects of stream blockages and physical habitat on the distribution 
and abundance of American eel (Anguilla rostrata) in Maryland. M.S. thesis, Appalachian Laboratory, Frostburg, Maryland.

Wiley, D., R.P. Morgan, and R.H. Hilderbrand. 2004. Relations between physical habitat and American eel abundance in five river basins in Maryland. Transactions of the American Fisheries Society 133: 515-526.

Winn, H.E., L.K. Winn, and W.A. Richkus. 1975. Sexual dimorphism and natural movements of the American eel (Anguilla rostrata) in Rhode Island streams and estuaries. Helgolander Meeresunters 27, 156-166.

Wippelhauser, G.S., and J.D. McCleave. 1988. Rhythmic activity of migrating juvenile American eels Anguilla rostrata. Journal of Marine Biology Association U.K. 68: 81-91. 
CHAPTER 2: Environmental variables associated with upstream migration and length and age of American eels at the Millville Dam eel ladder, Shenandoah River, West Virginia.

\section{Introduction}

Abundances of American eel (Anguilla rostrata) have declined along the east coast of the United States and Canada (ASMFC 2004). Population declines possibly result from human influences such as habitat loss (Wiley 1999, Casselman 2003, Tremblay 2005), over harvesting (Appelbaum et al. 1998, Haro et al. 2000, Patrick et al. 2000, Casselman 2003), pollution (Castonguay et al. 1994) or barriers to migration, such as dams (Wiley 1999, Neraas and Spruell 2001, Wiley et al. 2004). In response to recent population fluctuations, the Atlantic States Marine Fisheries Commission (ASMFC) drafted an eel management plan (Euston et al. 1998, ASMFC 1999, Patrick et al. 2000) and recommended research of both up and downstream eel passage at hydroelectric dams (ASMFC 1999, Patrick et al. 2000).

Population declines possibly result from multiple causes of mortality within all American eel life phases (leptocephalus, glass, elver, yellow, and silver); however, the yellow phase encompasses most of the lifespan (7-30 years in freshwater systems, Able and Fahay 1998). Since many yellow-phase eels migrate long distances upstream within river systems (Laffaille et al. 2005) and ultimately become large fecund females in silver-

phase (Helfman et al. 1987), range reductions of yellow eels owing to upstream migration barriers possibly contribute to population declines (White and Knights 1997, Agostinho et al. 2002, Laffaille et al. 2005). Dams fragment habitat and detain upstream migration of eels (Haro et al. 2000), and are distributed widely within and among Atlantic coast river drainages (Casselman 2003). Specifically, in the St. Lawrence River watershed, a 
total of 8,411 dams (at least $2.5 \mathrm{~m}$ high) limit eel access to $12,140 \mathrm{~km}^{2}$ of freshwater habitats of $10 \mathrm{~m}$ or less in depth (Castonguay et al. 1994). Eel abundances within watersheds decrease naturally with increased distance from the ocean; hence, longitudinal patterns of eel distributions within river drainages with dams are equivocal indicators of population status (Wiley et al. 2004, Laffaille et al. 2005).

Dams also detain upstream movement of juveniles (Levesque 1978, Goodwin and Angermier 2003, Haro et al. 2000). In Canada and Europe, eel ladders on hydroelectric dams have allowed access to upstream habitat (a management goal), but also have promoted eel research and provided data on upstream migration and recruitment of yellow phase eels (i.e., a source of data useful for management). Studies of eel ladders have focused on conspecific detection (Briand et al. 2002), upstream movement (Casselman et al. 1997, McGrath et al. 2003, Verdon et al. 2003), ladder design requirements (Verreault et al. 1994, Knights and White 1998, Verdon et al. 2003), harvest impacts on movement (Verdon and Desrochers 2003), and temporal variations in size structure (Laffaille et al. 2005). A lack of information on upstream movement of yellow eels in upper tributary reaches of Atlantic coast drainages results partly from an absence of eel ladders.

Few studies exist on age class composition and age-length relationships of migrant yellow-phase American eels or on environmental cues to upstream migration of yellow eels in upper reaches of Atlantic coast watersheds. Studies from estuaries, estuary/freshwater interfaces, and tidally-influenced freshwaters have documented a wide range of lengths within age-classes of American eels (Ogden 1970, Helfman et al. 1984, Owens and Geer 2003), and have reported abiotic correlates to eel movements (Martin 1995, White and Knights 1997, Laffaille et al. 2003). Environmental correlates of eel 
movements include barometric pressure (Sorensen and Bianchini 1986, Baras et al. 1998, Euston et al. 1998), water temperature (Sorensen et al. 1986, Haro and Krueger 1988 and 1991, Verdon et al. 2003), river flow (Hammond 2003, Laffaille et al. 2003), and lunar phase (Hammond 2003, Lamothe et al. 2000).

This study examined upstream migration of yellow-phase American eels at an eel ladder on Millville Dam, a hydroelectric facility on the lower Shenandoah River, West Virginia. Study objectives were to: (1) document numbers of eels entering the Shenandoah River drainage, (2) examine size and age structure of upstream migrants, and (3) examine relationships among environmental variables and upstream migration of American eels. The first two objectives were not hypothesis-driven, but rather focused on estimation of parameters associated with the number, size, and age of upstream migrants. For the third objective, we examined alternative hypotheses of environmental cues to upstream migration of yellow-phase eels. Although similar studies exist for estuaries and lower reaches of rivers, few studies have examined size and age composition, and upstream migration in upper watersheds. Due to the absence of dams downstream (of the Millville Dam) to detain upstream migrants, this study allowed us to assess the number of eels using the Shenandoah River.

\section{Methods}

Study site

The Shenandoah River drainage encompasses approximately $7,870 \mathrm{~km}^{2}$, and lies mostly in Virginia within the Valley and Ridge physiographic province, with some tributaries flowing out of the Blue Ridge province (Jenkins and Burkhead 1994). The drainage consists primarily of the North Fork and South Fork of the Shenandoah River, each flowing for over $250 \mathrm{rkm}$ before forming the Shenandoah River at Front Royal, VA. 
At Harper's Ferry, WV, the Shenandoah converges with the Potomac River (a large Chesapeake Bay drainage). The Millville dam (owned and operated by Allegheny Energy) is a low head dam located $7.24 \mathrm{~km}$ from the confluence of the Potomac and Shenandoah Rivers at Harper's Ferry, WV, and 249 rkm from the mouth of the Potomac River at the head of tide. The 700-m wide Millville Dam has a head of 5m, and a total generating capacity of approximately $1.8 \mathrm{MW}$.

\section{Ladder Design and Placement}

The eel ladder, a covered metal sluice, slopes $50^{\circ}$ and extends $11 \mathrm{~m}$ on the western end of the dam (Appendix 1). An attraction flow (>10 1/s) adjacent to the ladder base gravitates through a PVC pipe from the top of the dam (Appendix 2). A pool at the base of the ladder results from flashboards on the face of the dam and enables eels to distinguish between spillway and attraction flows (Appendix 2). An internal facilitation flow $(0.5 \mathrm{l} / \mathrm{s})$ pumps from the top of the ladder and provides a constant "upstream current" and to facilitate eel use of the ladder (Appendix 2). In addition, three rows of vertically-placed PVC pipe act as a "peg board" substrate to further facilitate movement (Appendix 2). A pipe at the top of the ladder passes through the dam and enters into a collection tank (Appendix 2). Within the collection tank, the PVC pipe connects to a double net system, including a $2.13 \mathrm{~m}$ long $(60.96 \mathrm{~cm}$ diameter with $6.35 \mathrm{~mm}$ mesh) net, inserted into a $2.74 \mathrm{~m}$ long $(60.96 \mathrm{~cm}$ diameter with $9.53 \mathrm{~mm}$ mesh $)$ net. This double net design separates small and large eels thereby easing removal of eels from the tank and reducing possibility of predation.

\section{Data Collection}

Eels within the collection tank were counted daily during three sampling periods; late spring/summer 2004 (May 14-July 23), fall 2004 (Aug-Sept 24), and late 
spring/summer 2005 (June 1-July 31). A total count of eels was recorded from an initial study of ladder efficacy during late summer/fall 2003 (Aug 28-Sept 17); however, numbers of eels were not always counted daily during this efficacy study. The three sampling periods (after the efficacy study) were not selected by study design, but rather were determined by discretion of the hydroelectric power company (based on weather and flow conditions) and on periods of dam construction. Ladder installations during the spring of 2004 (May 14) and 2005 (June 1) were delayed until after a decrease in spring flows (allowing workers access to the dam spillway). Dam construction ended the late spring/summer sampling periods of 2004 and 2005, because dewatered tailwaters prevented eel access to the ladder. The fall 2004 sampling period began when river flows allowed access to the ladder, and included several high hurricane-induced flow events (the latter event removed the ladder and ended the fall sampling period).

Eels were collected daily during the three primary sampling periods, and calmed in an ice slurry for weights (g) and measures (TL cm). Eels collected during the 2003 efficacy study were also counted and measured (TL cm). After collection of length and weight data, eels were acclimated to ambient water temperatures and released $0.40 \mathrm{~km}$ upstream of the dam.

Ages were estimated from a subsample of eels by sagittal otolith analysis. Sagittal otoliths were extracted following methods of Oliveira (1996). Before cross sectional analysis, otoliths were fixed in epoxy to prevent fragmentation of thin sections and to stabilize the otolith while cutting. Sections of otoliths were obtained by saw (Buehler Isomet 1000, Germany), and prepared, set, and stained following procedures of Secor et al. (1992) and Oliveira (1996). Estimates of age included one year for 
leptocephalus and glass eel phases (Helfman et al. 1984). All counts were triple checked before a subsample was double checked by a blind count.

We collected daily measures of five environmental variables: river flow, lunar phase, water temperature, local precipitation, and barometric pressure. River discharge (cubic meters per second, cms) was obtained from the U.S. Geological Survey gage at Millville Dam (http://waterdata.usgs.gov), and is hereafter referred to as river flow. We quantified percent lunar illumination as a range from 0 to 1 ; new moon (0.00), first and last quarter (0.50), and full moon (1.00); http://aa.usno.navy.mil/data/docs/MoonFraction.html). Onset temperature loggers recorded daily water temperatures both inside the collection tank and at the hydroelectric facility. Local precipitation was recorded daily at the hydroelectric facility with a Hobo event rain gage (model number 1001-056). Daily measures of barometric pressure were downloaded from (http://www.wunderground.com/weatherstation/WXDailyHistory).

\section{Data Analyses}

Parameter estimates of length, weight, and age described the size and age composition of eels, and those of environmental variables summarized means and variation of site and sampling conditions. We estimated mean length at age, and regressed and plotted age-length relationships. Length-weight relationships were calculated with data from all individuals using the equation $\mathrm{w}=\mathrm{aL}^{\mathrm{b}}$ where parameters a and $\mathrm{b}$ were estimated given data of weight $(\mathrm{g})$ and total length $(\mathrm{cm})$ (Murphy and Willis 1996). Differences in environmental conditions among sampling periods were depicted with estimates of within-sample means of environmental variables (and associated variation). 
A total of 22 biologically-reasonable candidate models were fit to daily count data from the spring/summer sampling periods of 2004 and 2005. Candidate models included combinations of four environmental covariates and a year effect (Table 1). The 22 candidate models (selected before analysis and representing multiple hypotheses, Chamberlin 1965) were ranked by an overdispersion-corrected second-order adjustment to Akaike's information criterion $\left(\mathrm{QAIC}_{\mathrm{c}}\right)$. The $\mathrm{QAIC}_{\mathrm{c}}$ and other model selection statistics were derived from calculations from the DIST $=$ NEGBIN option in PROC GENMOD of the Statistical Analysis System (SAS; Littell et al. 2002). This information-theoretic approach, where $\mathrm{QAIC}_{\mathrm{c}}$ estimates Kullback-Leibler distance, selects the best model (or suite of competing models) through a parsimonious tradeoff among bias, variance, and the number of estimable model parameters (Burnham and Anderson 2003).

\section{$\underline{\text { Results }}$}

A total of 4,847 eels used the ladder during the three sampling periods; 1,384 during late spring/summer 2004 (May 14-July 23), 2,816 during fall 2004 (Sept 10-Sept 30), and 647 during summer 2005 (June 1-July 31). A total of 409 eels used the ladder in an initial study of ladder efficacy in late summer and fall 2003; however, these counts were not recorded daily and we included these data only in the frequency histograms. Daily eel counts fluctuated within and among the three sampling periods with peaks in 2004 on June $17(\mathrm{n}=236)$, June $18(\mathrm{n}=117)$, July $6(\mathrm{n}=219)$, Sept $12(\mathrm{n}=2072)$, and Sept $13(\mathrm{n}=550)$, and in 2005 on July $10(\mathrm{n}=96)$, July $11(\mathrm{n}=92)$, and July $19(\mathrm{n}=160)$. The fall 2004 sampling period was also excluded from environmental covariate analysis; large numbers of eels were associated with an atypical hurricane-induced flow event after a 48$\mathrm{d}$ period of dewatered tailwaters and ladder closure. 
The spring/summer sampling periods of 2004 and 2005 were relatively similar in environmental conditions, although a higher mean river flow occurred in 2004 (Table 2). The fall 2004 sampling period, however, experienced highest flows owing to hurricaneinduced storm events (Table 2). The spring/summer sampling period of 2004 included two full moons and three new moons, and that of 2005 encompassed two full moons and two new moons. Daily water temperatures were not used as an analysis covariate because daily values were relatively constant within each sampling period (Table 2). Barometric pressure varied among days within sampling periods, but variation occurred within a narrow range (Table 2). Local precipitation varied widely within sampling periods, although mean values were similar among sampling periods (Table 2). In general, high river flows resulted from rain events within upstream sections of the Shenandoah River watershed, and were not associated with local precipitation.

Eel size was similar among sampling periods; summer/fall 2003 (range 19.7-51 cm TL, $\mu=30.4 \mathrm{~cm}$ TL; Figure 1A), spring/summer 2004 (range 20-69 cm TL, $\mu=29.4$ cm TL; Figure 1B), fall 2004 (range 20.6-70 cm TL, $\mu=33.5 \mathrm{~cm}$ TL; Figure 1C), and summer 2005 (range 19-53 cm TL, $\mu=30.1 \mathrm{~cm}$ TL; Figure 1D). The length-weight relationships were also similar among sampling periods; spring/summer $2004(\mathrm{w}=$ $\left.0.0011 L^{3.0719}, R^{2}=0.8436\right)$, fall $2004\left(w=0.001 L^{3.0873}, R^{2}=0.9194\right)$, and summer 2005 $\left(\mathrm{w}=0.0008 \mathrm{~L}^{3.1527}, \mathrm{R}^{2}=0.8961\right.$; Figure 2$)$. Age estimates from 74 eels $(21.4-55 \mathrm{~cm}$ TL) ranged from 3 to 10 (Table 3, Figure 3A). Mean weights g ( $\mathrm{N}$ and standard error) for ages 3 through 9 were $26.7(4,14.3), 42(16,7.1), 33.9(18,6.7), 48.2(17,6.9), 73(13$, 7.9), 68(3, 16.5), and 223.0(2, 20.2), respectively (Figure 3B). Age-length and ageweight regressions revealed $R^{2}$ values of 0.329 and 0.308 , respectively (Figures $3 \mathrm{~A}, 3 \mathrm{~B}$ ). 
During the two spring/summer sampling periods of 2004 and 2005, peaks in eel counts coincided primarily with low levels of lunar illumination (near new moon) or with rise in river flow (Figures 4A, 4B). The additive model of lunar illumination and river flow was the best approximating model with $\mathrm{QAIC}_{\mathrm{c}}$ weight of 0.99 (Table 4). The other 21 models (i.e. hypotheses) were not supported by the data, and only one other model received weight (the river flow model with weight of 0.01 ; Table 4 ). The data did not support single-variable or additive models with covariates of barometric pressure or local precipitation, or models with a year effect.

\section{$\underline{\text { Discussion }}$}

In this study, the size composition, age structure, and migratory cues of upstream migrant yellow-phase American eels were examined through daily collections of eels from an eel ladder. This sampling approach led to several important results. First, we documented large numbers of yellow-phase American eels migrating upstream during summer and fall in an upper watershed (Shenandoah River) of the Potomac River drainage. Second, estimates of mean length at age of eels from Shenandoah River were low relative to published estimates from southern and northern latitudes. Third, low levels of lunar illumination and rises in river flow were important environmental changes associated with upstream migration of yellow-phase eels in the lower Shenandoah River. Data did not support local precipitation, barometric pressure, or water temperature as environmental variables associated with upstream migration during the late spring/summer sampling periods.

\section{Length and Age}

Based on averages of mean length at age data for ages 3-9, eels from the lower Shenandoah River grew slower than those from Newfoundland, Canada $(4.1 \mathrm{~cm}$, Gray 
and Andrews 1971), tributaries (James, York, and Rappahannock rivers) of Chesapeake Bay, VA (8.7 cm, Owens and Geer 2003) and Cooper River, SC (16.0 cm, Hansen and Eversole 1984). Literature supports a latitudinal difference in growth rates of eels on the Atlantic coast, where northern populations grow slower those of southern populations (see review in Owens and Geer 2003); hence, the large difference was expected between Shenandoah and Cooper river estimates of mean length at age. Given latitudinal differences, however, one would expect growth rates of eels from Shenandoah River to be relatively similar to those of Chesapeake Bay tributaries, VA, and greatly exceed those from Newfoundland. Although Shenandoah River and Virginia tributaries drain to Chesapeake Bay (i.e., share latitudinal similarity), study locations differ by distance to the estuary. Data from VA tributaries were collected from the river mouths to approximately river km 72 (Owens and Geer 2003), and those from the Shenandoah River were collected at approximately river $\mathrm{km} 249$ (upstream of head of tide). Yellowphase eels in upper reaches of watersheds likely budget more energy for migration (and less for growth) than those closer to the estuary. The longitudinal difference (i.e., distance from estuary) in study location and energy trade-offs between migration and growth, possibly explain differences among mean length at age between eel samples from Shenandoah River and tributaries of Chesapeake Bay, VA. Although an average of mean lengths at age for ages 3-9 differed between data from Shenandoah River and Newfoundland, the difference was not consistent among individual age classes. Mean length at age for ages 3 and 4 from the Shenandoah River exceeded those from Newfoundland by 4.9 and $3.4 \mathrm{~cm}$, respectively. However, mean length at age for ages 59 from Newfoundland exceeded those from the Shenandoah River by 3.0, 2.5, 12.6, 14.1, $4.8 \mathrm{~cm}$, respectively. This possibly results from combined effects of latitude and 
longitude (distance from estuary), where the latitude effect dominates the early age classes, and older ages are influenced by the energy trade-off of growth and migration.

The wide range of lengths within each age class of Shenandoah River eels corroborates findings from a wide latitudinal geographic range; Altamaha River, GA (Helfman et al. 1984), Cooper River, SC (Harrell and Loyacano 1976), Chesapeake Bay tributaries, VA (Owens and Geer 2003), Atlantic coast tributaries, NJ (Ogden 1970), Hudson River, NY (Morrison and Secor 2003), Lake Champlain, VT (Facey and LaBar 1981), and eastern Lake Ontario, Canada (Hurley 1972). Owens and Geer (2003) generalize two possible explanations for the wide range of lengths within an age class; variable growth rates among individual yellow eels or problems with aging. My study does not provide an explanation of the wide range of lengths within age classes of American eels, but does document its occurrence in an upper watershed of the Potomac River drainage.

\section{Environmental Variables}

The data supported lunar illumination and river flow as environmental variables associated with upstream migration of yellow-phase eels in the lower Shenandoah River. Previous research on eel movements has concentrated primarily on lunar phase (Hain 1975, Winn et al. 1975, Dutil et al. 1989, Parker 1995, Baras et al. 1998, Lamothe et al. 2000, and McGrath et al. 2003) as opposed to river flow (Laffaille et al. 2003), and few studies have emphasized the importance of both variables (Verdon et al. 2003). The use of covariates within models precludes strong inference from analysis of observational data, because relationships are only correlative (White 2002). Researchers have suggested that low light availability (due to increased turbidity and river flow) and low levels of lunar illumination synergistically cue upstream migration of eels (Dutil et 
al. 1988). Lunar influences on eel migration may result from light rather than a periodic effect (Hain 1975). The effect of lunar illumination and river flow on eel movements in the Shenandoah River may also be unmeasured variables related to light such as cloud cover and turbidity. We speculate that lunar illumination and river flow (or unmeasured correlates of these two variables) would also be associated with eel movements elsewhere in the Potomac River drainage, as well as within other Atlantic coast watersheds.

Our data did not support a relationship between upstream movement and barometric pressure, local precipitation or water temperature, although numerous studies have reported a relationship of these three variables either separately or synergistically (Liew 1978, Sorensen and Bianchini 1986, Baras et al. 1988, Dutil et al. 1988, Haro and Krueger 1991, White and Knights 1997, and Verdon and Desrochers 2003). We collected data primarily during late spring, summer, and fall; hence, our results are not transferable to winter and spring periods during which barometric pressure, local precipitation, or water temperature may be important. Yellow-phase eels are torpid during water temperatures below $10^{\circ} \mathrm{C}$ (Walsh et al. 1983), and the onset of upstream migration during spring coincides with a $10-16^{\circ} \mathrm{C}$ range of water temperatures (EPRI 1999). We did not examine the influence of spring water temperatures on eel movement given the dates of ladder installation. Other studies have documented sunlight, barometric pressure, local precipitation, or air and water temperatures as correlates with the onset of upstream migration (Winn et al. 1975, Sorensen and Bianchini 1986, Baras et al. 1998, Euston et al. 1998).

\section{Implications for management and research}

This study of an eel ladder documented large numbers of migrant yellow-phase eels in the lower Shenandoah River, a finding that supports important implications for 
management and research. First, results support the efficacy of eel ladders and promote a management strategy for allowing eels access to additional habitat in upper watersheds. Second, eel ladders (when used as a passive collection gear) provide managers with valuable data on eel numbers and migration. With long-term deployment, an eel ladder will provide time-series data for examination of seasonal or annual trends, a current management need given population declines.

Managers cannot decouple ladder-induced upstream migration of yellow eels from downstream migration of silver eels. Increasing numbers of yellow eels upstream of hydroelectric dams via ladders require further consideration of turbine mortality of outmigrant silver eels. Turbine mortality can exceed 25\% (EPRI 1999) with some estimates exceeding 50\% (Ritter et al. 1997, Verreault and Dumont 2000). Some hydroelectric facilities schedule turbine shutdowns to reduce turbine mortality; Allegheny Energy provides night-time shutdown of turbines during fall downstream migration (Chuck Simons, personal communication). Management strategies for American eels will benefit from short and long-term studies of eel ladders, including additional focus on eel counts, size and age composition, and upstream migration, as well as further research of silver outmigrants. 


\section{Literature Cited}

Able, K.W., and M.P. Fahay. 1998. The first year in the life of estuarine fishes in the middle Atlantic bight. Rutgers University Press, Livingston Campus, New Brunswick, New Jersey Pages 38-41.

Agostinho, A.A, L.C. Gomes, D.R. Fernandez, and H.I. Suzuki. 2002. Efficiency of fish ladders for neotropical ichthyofauna. River Research and Applications 18: 299306.

Appelbaum, S., A. Chernitsky, and V. Birkan. 1998. Growth observations on European (Anguilla anguilla) and American (Anguilla rostrata) glass eels. The Bengis Centre for Desert Aquaculture, Ben-Gurion University of the Negev, Israel.

Atlantic States Marine Fisheries Commission (ASMFC). 1999. Interstate Fishery management plan for American eel. ASMFC Fishery Management Report No. 36, Washington, D.C.

Atlantic States Marine Fisheries Commission (ASMFC). 2004. Review of the Atlantic States Marine Fisheries Commission Management plan for American eel. Washington, D.C.

Baras, E., D. Jeandrain, B. Serouge, and J.C. Philippart. 1998. Seasonal variations in time and space utilization by radio-tagged yellow eels Anguilla anguilla in a small stream. Hydrobiologia 371/372: 187-198.

Briand, C., D. Fatin, and A. Legault. 2002. Role of eel odor on the efficiency of an eel, Anguilla anguilla, ladder and trap. Environmental Biology of Fishes 65: 473-477.

Burnham, K.P. and D.R. Anderson. 2002. Model selection and multi-model inference: a practical information-theoretic approach, Second Edition. Springer, New York, New York. 
Casselman, J.M., A. Marcogliese, and P.V. Hodson. 1997. Recruitment index for the upper St. Lawrence River and Lake Ontario eel stock: a re-examination of eel passage at the R.H. Saunders hydroelectric generating station at Cornwall, Ontario 1974-1995. Canadian Technical Report of Fisheries and Aquatic Sciences 2196: 161-169.

Casselman, J.M. 2003. Dynamics of resources of the American eel, Anguilla rostrata: declining abundance in the 1990s.,Eel Biology, Springer-Verlag Tokyo, Japan. pp. $255-274$

Castonguay, M., P.V. Hudson, C.M. Couillard, M.J. Eckersley, J.D. Dutil, and G. Verreault. 1994. Why is recruitment of the American eel, Anguilla rostrata, declining in the St. Lawrence River and Gulf? Canadian Journal of Fisheries and Aquatic Sciences 51: 479-488.

Chamberlin, T.C. 1965. The method of multiple working hypotheses. Science 148: 754759.

Dutil, J.-D., A. Giroux, A. Kemp, G. Lavoie, and J.P. Dallaire. 1988. Tidal influence on movements and on daily cycle of activity of American eels. Transactions of the American Fisheries Society 117: 488-494.

Dutil, J.-D., M. Michaud, and A. Giroux. 1989. Seasonal and diel patterns of stream invasion by American eels (Anguilla rostrata) in the northern Gulf of St. Lawrence. Canadian Journal of Zoology 67: 182-188.

Electric Power Research Institute. 1999. American eel (Anguilla rostrata) scoping study: a literature and data review of life history, stock status, population dynamics, and hydroelectric impacts. TR-11873 Palo Alto, California. 
Euston, T. E., D.D. Royer, and C.L. Simons. 1998. American eels and hydro plants: clues to eel passage. Hydro Review 94-103.

Facey, D.E., and G. W. LaBar. 1981. Biology of American eels in Lake Champlain, Vermont. Transactions of the American Fisheries Society 110:396-402.

Gray, R.W., and C.W. Andrews. 1971. Age and growth of the American eel (Anguilla rostrata Lesueur) in Newfoundland waters. Canadian Journal of Zoology 48: 483487.

Goodwin, K. R., and P.L. Angermeier. 2003. Demographic characteristics of American eel in the Potomac River drainage, Virginia. Transactions of the American Fisheries Society 132:524-535.

Hain, J.H.W. 1975. The behavior of migratory eels, Anguilla rostrata, in response to current, salinity, and lunar period. Helgolander Meeresuntersuchungen 27: 211233.

Hammond, S. 2003. Seasonal movements of yellow-phase American eels (Anguilla rostrata) in the Shenandoah River, West Virginia. M.S. thesis. West Virginia University, Morgantown, West Virginia.

Hansen, R.A., and A.G. Eversole. 1984. Age, growth, and sex ratio of American eels in brackish-water portions of a South Carolina river. Transactions of the American Fisheries Society 113: 744-749.

Haro, A.J., and W.H. Kreuger. 1988. Pigmentation, size, and migration of elvers (Anguilla rostrata) in a coastal rhode island stream. Canadian Journal of Zoology 66:2528-2533. 
Haro, A. J., and W.H. Krueger. 1991. Pigmentation, otolith rings, and upstream migration of juvenile American eels (Anguilla rostrata) in a coastal Rhode Island stream. Canadian Journal of Zoology 69: 812-814.

Haro, A., T. Castro-Santos, and J. Boubee. 2000. Behavior and passage of silver-phase American eels, Anguilla rostrata (LeSueur), at a small hydroelectric facility. Dana 12: 33-42.

Harrell, R.M., and H.A. Loyacano. 1976. Age, growth, and sex ratio of the American eel in the Cooper River, South Carolina. Proceedings of the Annual Conference of the Southeastern Association of Fish and Wildlife Agencies 34: 349-359.

Helfman, G.S., E.L. Bozeman, and E.B. Brothers. 1984. Size, age, and sex of American eels in a Georgia river. Transactions of the American Fisheries Society 113:132141.

Helfman, G.S., D.E. Facey, L.S. Hales, Jr., and E.L. Bozeman. 1987. Reproductive ecology of the American eel. American Fisheries Society Symposium 1: 42-56.

Hurley, D.A. 1972. The American eel (Anguilla rostrata) in eastern Lake Ontario. Journal of the Fisheries Research Board of Canada 29:535-543.

Jenkins, R. E., and N. M. Burkhead. 1994. Freshwater Fishes of Virginia. American Fisheries Society, Bethesda, Maryland.

Knights, B., and M. White, 1998. Enhancing immigration and recruitment of eels: the use of passes and associated trapping systems. Fisheries Management and Ecology 5: $459-471$.

Laffaille, P., E. Feunteun, A. Baisez, T. Robinet, A. Acou, A. Legault, and S. Lek. 2003. Spatial organisation of European eel Anguilla anguilla in a small catchment. Ecology of Freshwater Fish 12: 254-264. 
Laffaille, P., A. Acou, J. Guillouet, and A. Legault. 2005. Temporal changes in European eel, Anguilla anguilla, stocks in a small catchment after installation of fish passes. Fisheries Management and Ecology 12: 123-129.

Lamothe, P.J., M. Gallagher, D.P. Chivers, and J.R. Moring. 2000. Homing and movement of yellow-phase American eels in freshwater ponds. Environmental Biology of Fishes 58: 393-399.

Levesque, J.R. 1978. The effects of dams on American eel in the Thames River Watershed, Connecticut. M.S. thesis, University of Connecticut.

Liew, P.K.L. 1974-1978. Impact of the eel ladder on the upstream migrating eel (Anguilla rostrata)population in the St. Lawrence River at Cornwall. Ontario Ministry of Natural Resources Pgs 17-21.

Littell, R.C., W.W. Stroup, and R.J. Freund. 2002. SAS system for linear models. $4^{\text {th }}$ edition. SAS Institute, Cary, North Carolina.

Lowe, R.H. 1952. The influence of light and other factors on the seaward migration of the silver eel (Anguilla rostrata L.). Journal of Animal Ecology 21: 275-309.

Martin, M.H. 1995. The effects of temperature, river flow, and tidal cycles on the onset of glass eel and elver migration into fresh water in the American eel. Journal of Fish Biology 46: 891-902.

McGrath, K.J., D. Desrochers, C. Fleury, and J.W. Dembeck. 2003. Studies of upstream migrant American eels at the Moses-Saunders Power Dam on the St. Lawrence River near Massena, New York. . In D.A. Dixon (ed). Biology, Management, and Protection of Catadromous Eels. Bethesda MD, USA: American Fisheries Society, Symposium 33:153-166.

Moriarty, C. and W. Dekker. 1997. Management of the European eel. Second report of 
the EU concerted action AIR A94-1939. Fisheries Bulletin No. 15, Dublin: The Marine Institute, $110 \mathrm{pp}$.

Morrison, W.E. and D.H. Secor. 2003. Demographic attributes of yellow-phase American eels (Anguilla rostrata) in the Hudson River estuary. Canadian Journal of Fisheries Aquatic Sciences 60: 1487-1501.

Murphy, B.R., and D.W.Willis. 1996. Fisheries Techniques: $2^{\text {nd }}$ edition. American Fisheries Society, Bethesda, Maryland.

Neraas, L. P., P. Spruell. 2001. Fragmentation of riverine systems: the genetic effects of dams on bull trout (Salvelinus confluentus) in the Clark Fork River System. Molecular Ecology 10: 1153-1164.

Ogden, J.C. 1970. Relative abundance, food habits, and the age of the American eel, Anguilla rostrata (LeSueur) in certain New Jersey streams. Transactions of the American Fisheries Society 99:54-59.

Oliveira, K. 1999. Life history characteristics and strategies of the American eel, Anguilla rostrata. Canadian Journal of Fisheries Aquatic Sciences 56:795-802.

Oliveira, K. 1997. Movements and growth rates of yellow-phase American eels in the Annaquatucket River, Rhode Island. Transactions of the American Fisheries Society 126: 638-646.

Oliveira, K. 1996. Field validation of annular growth rings in the American eel, Anguilla rostrata, using tetracycline-marked otoliths. Fishery Bulletin 94: 186-189.

Oliveira, K., and J.D. McCleave. 2002. Sexually different growth histories of the American eel in four rivers in Maine. Transactions of the American Fisheries Society 131:203-211.

Oliveira, K., and J.D.McCleave. 2000. Variation in population and life history traits of 
the American eel, Anguilla rostrata, in four rivers in Maine. Environmental Biology of Fishes 59: 141-151.

Owens, S.J. and P.J. Geer. 2003. Size and age of American eels collected from tributaries of the Virginia portion of Chesapeake Bay. . In D.A. Dixon (ed). Biology, Management, and Protection of Catadromous Eels. Bethesda MD, USA: American Fisheries Society, Symposium 33:117-124.

Parker, S.J. 1995. Homing ability and home range of yellow-phase American eels in a tidally dominated estuary. Journal of Marine Biology Assoication U.K. 75: 127140.

Patrick, P. H., S.J. Poulton, and R. Brown. 2000. Using strobe lights and sound to protect American eels. Hydro Review 98-102.

Powles, P. M., and S.M. Warlen. 2001. Recruitment season, size, and age of young American eels (Anguilla rostrata) entering an estuary near Beaufort, North Carolina. Fisheries Bulletin 100: 299-306.

Ritter, J.A., M. Stanfield, and R.H. Peterson. 1997. Final Discussion, p. 170-172. In R.H. Peterson (ed) The American eel in eastern Canada: stock status and management strategies. Proceedings of eel management workshop, January 13-14, 1997, Quebec City, PQ. Canadian Technical Report of Fisheries and Aquatic Sciences 2196.

Secor, D.H., J.M. Dean, and E.H. Laban. 1992. Otolith removal and preparation for microstructural examination. In D.K. Stevenson and S.E. Compana (eds.), otolith microstructure examination and analysis. Canadian Special Publications of Fisheries Aquatic Sciences 117: 119-127.

Sorensen, P.W., and M.L. Bianchini. 1986. Environmental correlates of freshwater 
migration of elvers of the American eel in a Rhode Island brook. Transactions of the American Fisheries Society 115: 258-268.

Sorensen, P.W. 1986. Origins of the freshwater attractant(s) of migrating elvers of the American eel, Anguilla rostrata. Environmental Biology of Fishes 17:185-200.

Tremblay, V. 2005. COSEWIC Status report on the American eel Anguilla rostrata prepared for the Committee on the Status of Endangered Wildlife in Canada by Valerie Tremblay on behalf of the Canadian Eel Science Working Group. May 2005. pgs. 1-43.

Verdon, R., D. Desrochers. 2003. Upstream migratory movements of American eel Anguilla rostrata between the Beauharnois and Moses-Saunders Power Dams on the St. Lawrence River. . In D.A. Dixon (ed). Biology, Management, and Protection of Catadromous Eels. Bethesda MD, USA: American Fisheries Society, Symposium 33: pp. 139-151.

Verdon, R., D. Desrochers, and P. Dumont. 2003. Recruitment of American eels in the Richelieu River and Lake Champlain: provision of upstream passage as a regional-scale solution to a large-scale problem. In D.A. Dixon (ed). Biology, Management, and Protection of Catadromous Eels. Bethesda MD, USA: American Fisheries Society, Symposium. 33. pp.125-138.

Verreault, G., P. Pettigrew, R. Tardif, and G. Pouliot. 1994. The exploitation of the migrating silver American eel in the St. Lawrence River estuary, Quebec, Canada. In D.A. Dixon (ed). Biology, Management, and Protection of Catadromous Eels. Bethesda, MD, USA: American Fisheries Society, Symposium 33: pp. 225-234. Verrault, G., and P. Dumont. 2000. Escapement of eel from the upper St. Lawrence River. Abstract: $130^{\text {th }}$ Annual American Fisheries Society Meeting, St. Louis, Mo. 
August 20-24, 2000.

Walsh, P.J., G.D. Foster, and T.W. Moon. 1983. The effects of temperature on metabolism of the American eel Anguilla rostrata compensation in the summer and torpor in the winter. Physiological Zoology 56: 532-540.

White, E.M, and B. Knights. 1997. Dynamics of upstream migration of the European eel, Anguilla anguilla (L.), in the Rivers Severn and Avon, England, with special reference to the effects of man-made barriers. Fisheries Management and Ecology 4: $311-324$.

White, G.C. 2002. Fitting population models to multiple sources of observed data. Journal of Wildlife Management 66(2):300-309.

Wiley, D. 1999. The effects of stream blockages and physical habitat on the distribution and abundance of American eel (Anguilla rostrata) in Maryland. M.S. thesis, Appalachian Laboratory, Frostburg, Maryland.

Wiley, D., R.P. Morgan, and R.H. Hilderbrand. 2004. Relations between physical habitat and American eel abundance in five river basins in Maryland. Transactions of the American Fisheries Society 133: 515-526.

Winn, H.E., L.K. Winn, and W.A. Richkus. 1975. Sexual dimorphism and natural movements of the American eel (Anguilla rostrata) in Rhode Island streams and estuaries. Helgolander Meeresunters 27, 156-166.

Wippelhauser, G.S., and J.D. McCleave. 1988. Rhythmic activity of migrating juvenile American eels Anguilla rostrata. Journal of Marine Biology Association U.K. 68: $81-91$. 
Table 1. List of models with corresponding hypotheses. Each of the 11 models was repeated with a year effect for a total set of 22 candidate models.

Model

Lunar illumination

River flow

Local precipitation

Barometric pressure

Lunar illumination + river flow

Lunar illumination + local precipitation

Lunar illumination + barometric pressure

River flow + local precipitation

River flow + barometric pressure

Local precipitation + barometric pressure

Local precipitation + barometric pressure + River flow + lunar illumination

\section{Hypothesis}

Lunar illumination associated with upstream migration

River flow associated with upstream migration

Local precipitation associated with upstream migration

Barometric pressure associated with upstream migration

Lunar illumination and river flow associated with upstream migration

Lunar illumination and local precipitation associated with upstream migration

Lunar illumination and barometric pressure associated with upstream migration

River flow and local precipitation associated with upstream migration

River flow and barometric pressure associated with upstream migration

Local precipitation and barometric pressure associated with upstream migration

All environmental variables associated with upstream migration 
Table 2. Mean, standard error (SE) and range of environmental variables depicted for three sampling periods of a study of upstream migration of American eels at the Millville Dam eel ladder, Shenandoah River, West Virginia.

\begin{tabular}{|c|c|c|c|c|c|c|c|c|c|}
\hline \multirow[b]{2}{*}{ Variable } & \multicolumn{3}{|c|}{ Spring/summer $2004(\mathrm{n}=71)$} & \multicolumn{3}{|c|}{ Fall $2004(n=21)$} & \multicolumn{3}{|c|}{ Spring/summer $2005(\mathrm{n}=61)$} \\
\hline & Mean & SE & Range & Mean & $\mathrm{SE}$ & Range & Mean & $\mathrm{SE}$ & Range \\
\hline River flow (cms) & 65.64 & 2.35 & $37.6-108.4$ & 222.79 & 53.50 & $51.2-1030.1$ & 48.07 & 2.59 & $27.2-115.2$ \\
\hline Barometric pressure & 30.02 & 0.02 & $29.68-30.39$ & 30.18 & 0.17 & 29.64-30.49 & 30.03 & 0.02 & $29.65-30.27$ \\
\hline Local precipitation & 9.28 & 3.64 & $0-226$ & 10.52 & 6.38 & $0-124$ & 10.16 & 4.69 & $0-255$ \\
\hline Water temperature $(\mathrm{C})$ & 23.17 & 0.18 & $21-25$ & 17.24 & 0.32 & $15-19$ & 26.70 & 0.32 & $18-30$ \\
\hline
\end{tabular}


Table 3. Mean total length $(\mathrm{cm})$ and standard error (SE) at age of American eels from a latitudinal range of Atlantic slope drainages.

\begin{tabular}{|c|c|c|c|c|c|c|c|c|c|c|c|}
\hline \multirow[b]{2}{*}{ Age } & \multicolumn{3}{|c|}{$\begin{array}{l}\text { Shenandoah River, } \\
\text { Millville Dam, WV }\end{array}$} & \multicolumn{3}{|c|}{$\begin{array}{l}\text { Chesapeake Bay tributaries, VA } \\
\text { (Owens and Geer 2003) }\end{array}$} & \multicolumn{3}{|c|}{$\begin{array}{c}\text { Cooper River, SC } \\
\text { (Hansen and Eversole 1984) }\end{array}$} & \multicolumn{2}{|c|}{$\begin{array}{l}\text { Newfoundland, Canada } \\
\text { (Gray and Andrews 1971) }\end{array}$} \\
\hline & $\mathrm{N}$ & Mean TL & $\mathrm{SE}$ & $\mathrm{N}$ & Mean TL & SE & $\mathrm{N}$ & Mean TL & $\mathrm{SE}$ & $\mathrm{N}$ & Mean TL \\
\hline 1 & & & & 7 & 17.6 & 2.9 & 2 & 29.2 & & & \\
\hline 2 & & & & 42 & 20.4 & 0.9 & 33 & 36.1 & 0.9 & 2 & 17.4 \\
\hline 3 & 4 & 26.9 & 2.6 & 162 & 27.4 & 0.8 & 97 & 41.1 & 0.7 & 6 & 22.0 \\
\hline 4 & 16 & 30.2 & 1.3 & 151 & 34.6 & 1.0 & 126 & 45.5 & 0.6 & 18 & 26.8 \\
\hline 5 & 18 & 28.8 & 1.2 & 124 & 45.1 & 1.2 & 108 & 48.2 & 0.7 & 27 & 31.8 \\
\hline 6 & 17 & 35.6 & 1.4 & 55 & 47.6 & 1.6 & 57 & 51.1 & 0.7 & 46 & 38.1 \\
\hline 7 & 13 & 32.2 & 1.2 & 18 & 49.3 & 3.7 & 9 & 58.0 & 2.1 & 42 & 44.8 \\
\hline 8 & 3 & 37.3 & 3.0 & 5 & 47.6 & 2.2 & 6 & 51.4 & 1.1 & 57 & 51.4 \\
\hline 9 & 2 & 53.3 & 3.6 & 6 & 53.6 & 4.3 & 3 & 61.1 & & 66 & 58.1 \\
\hline 10 & 1 & 40.2 & & 1 & 62.4 & & & & & 35 & 66.3 \\
\hline
\end{tabular}


Table 4. Model selection statistics, sample size (n), number of parameters (K), log likelihood values $(\log \mathrm{L})$, Akaike Information Criterion $\left(\mathrm{QAIC}_{\mathrm{c}}\right)$ values adjusted for small sample size and overdispersion, distance from lowest $\operatorname{QAIC}_{\mathrm{c}}\left(\Delta_{i}\right)$, and Akaike weights $\left(\mathrm{w}_{i}\right)$ from a set of 22 candidate models. Variables include a year effect (year) and environmental covariates: lunar illumination (lunar), river flow (flow), local precipitation (precip), and barometric pressure (bp).

\begin{tabular}{lcccccc}
\hline Model & $\mathrm{n}$ & $\mathrm{K}$ & $\mathrm{Log}(\mathrm{L})$ & $\mathrm{QAIC}_{\mathrm{c}}$ & $\Delta_{\iota}$ & $\mathrm{W}_{i}$ \\
\hline Lunar + flow & 131 & 5 & 4896.7 & -9782.9 & 0 & 0.99 \\
Flow & 131 & 4 & 4890.74 & -9773.2 & 9.76 & 0.01 \\
Lunar & 131 & 4 & 4881.67 & -9755 & 27.89 & 0 \\
Bp & 131 & 4 & 4878.71 & -9749.1 & 33.82 & 0 \\
Flow + year & 131 & 5 & 4878.69 & -9746.9 & 36.01 & 0 \\
Precip & 131 & 4 & 4878.06 & -9747.8 & 35.1 & 0 \\
Lunar + flow + year & 131 & 6 & 4864.85 & -9717 & 65.9 & 0 \\
Precip + flow & 131 & 5 & 4854.33 & -9698.2 & 84.74 & 0 \\
Flow + bp & 131 & 5 & 4852.45 & -9694.4 & 88.49 & 0 \\
Lunar + precip & 131 & 5 & 4843.84 & -9677.2 & 105.71 & 0 \\
Lunar + year & 131 & 5 & 4843.65 & -9676.8 & 106.1 & 0 \\
Lunar + bp & 131 & 5 & 4843.57 & -9676.7 & 106.27 & 0 \\
Bp + year & 131 & 5 & 4842.32 & -9674.2 & 108.76 & 0 \\
Precip + flow + year & 131 & 6 & 4842.02 & -9671.4 & 111.55 & 0 \\
Precip + year & 131 & 5 & 4841.22 & -9672 & 110.95 & 0 \\
Precip + bp & 131 & 5 & 4840.88 & -9671.3 & 111.64 & 0 \\
Flow + bp + year & 131 & 6 & 4839.7 & -9666.7 & 116.2 & 0 \\
Lunar + precip + year & 131 & 6 & 4805.83 & -9599 & 183.94 & 0 \\
Lunar + bp + year & 131 & 6 & 4805.46 & -9598.2 & 184.67 & 0 \\
Precip + bp + year & 131 & 6 & 4804.53 & -9596.4 & 186.53 & 0 \\
Lunar + precip + flow + bp + year & 131 & 8 & 4790.94 & -9564.7 & 218.21 & 0 \\
\hline
\end{tabular}



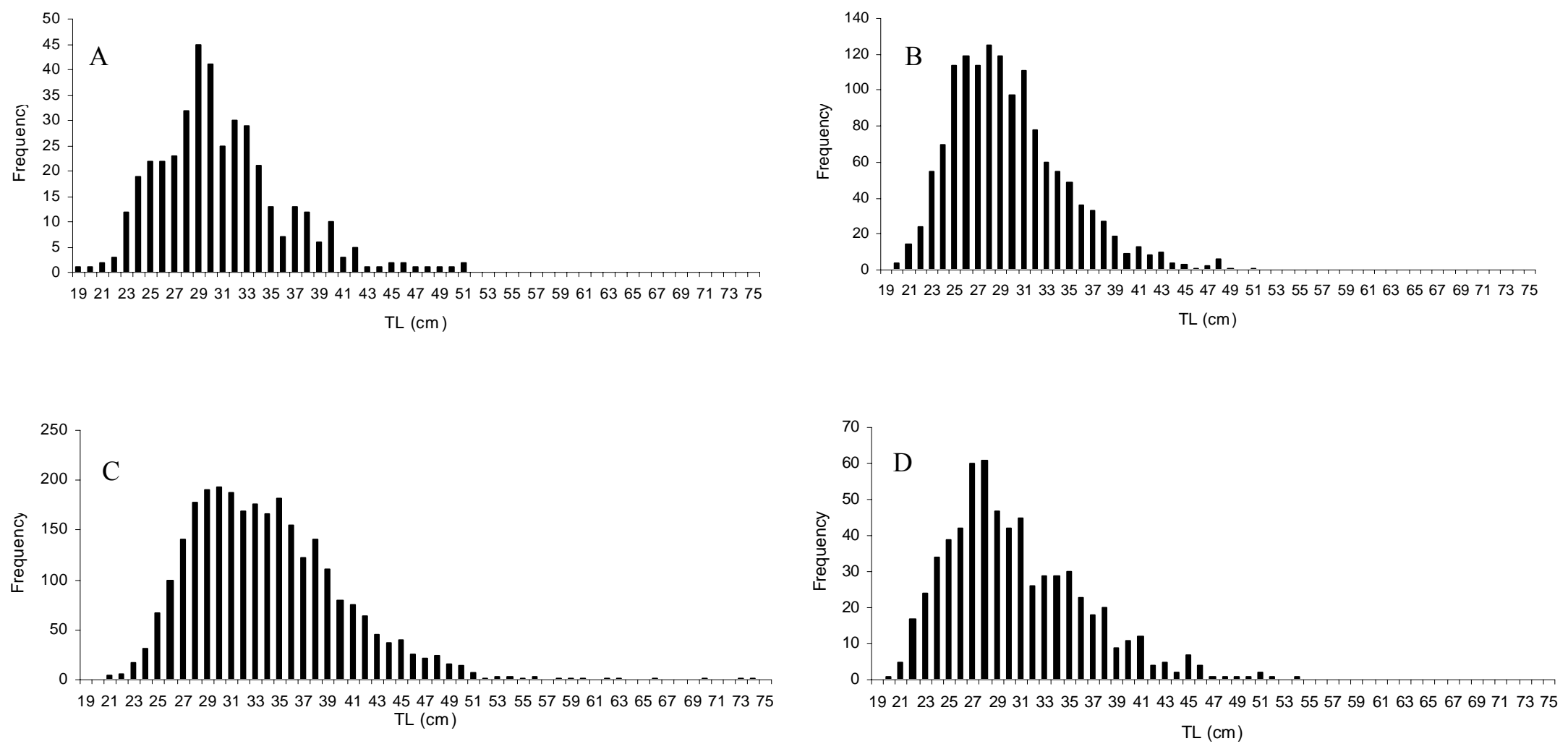

Figure 1. Length-frequency histograms of eels collected from the Millville Dam eel ladder during (A) Aug 28-Sept 17, 2003 $(\mathrm{N}=409 ; \mu=30.4 \mathrm{~cm}$ TL; range 19.7-51 cm), (B) May 14-July 23, $2004(\mathrm{~N}=1,384 ; \mu=29.4 \mathrm{~cm}$ TL; range 20-69 cm), and (C) Sept 10-30, $2004(\mathrm{~N}=2,542 ; \mu=33.5 \mathrm{~cm}$ TL; range 20-73 cm), and (D) June 1-July 31, $2005(\mathrm{~N}=647 ; \mu=30.1 \mathrm{~cm}$ TL; range $19-53 \mathrm{~cm})$. 


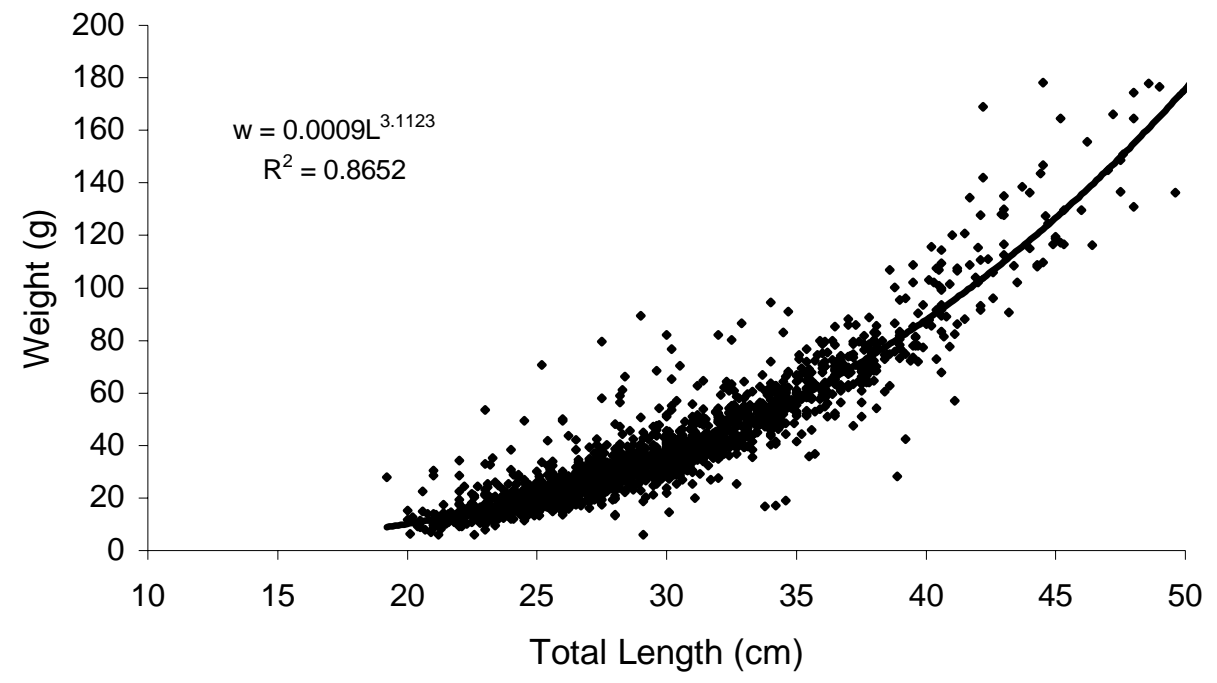

Figure 2. The length-weight relationship of eels $(\mathrm{N}=4,847)$ pooled from three sampling periods at the Millville Dam eel ladder, Shenandoah River, West Virginia. 
A)

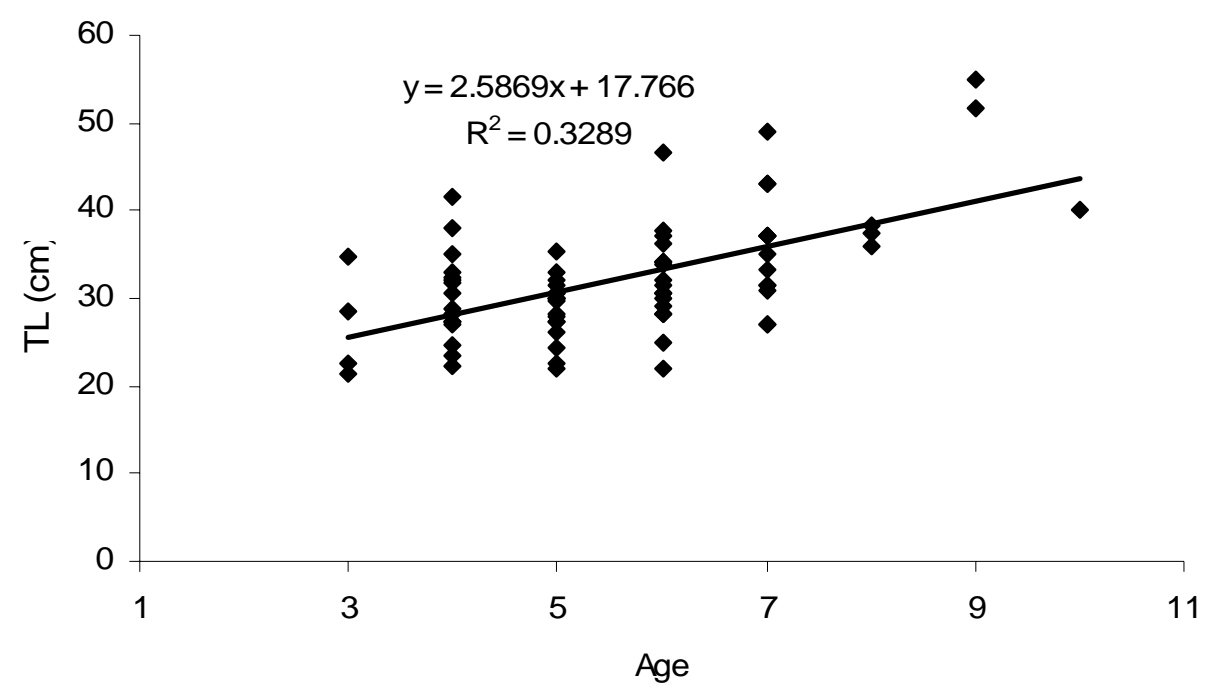

B)

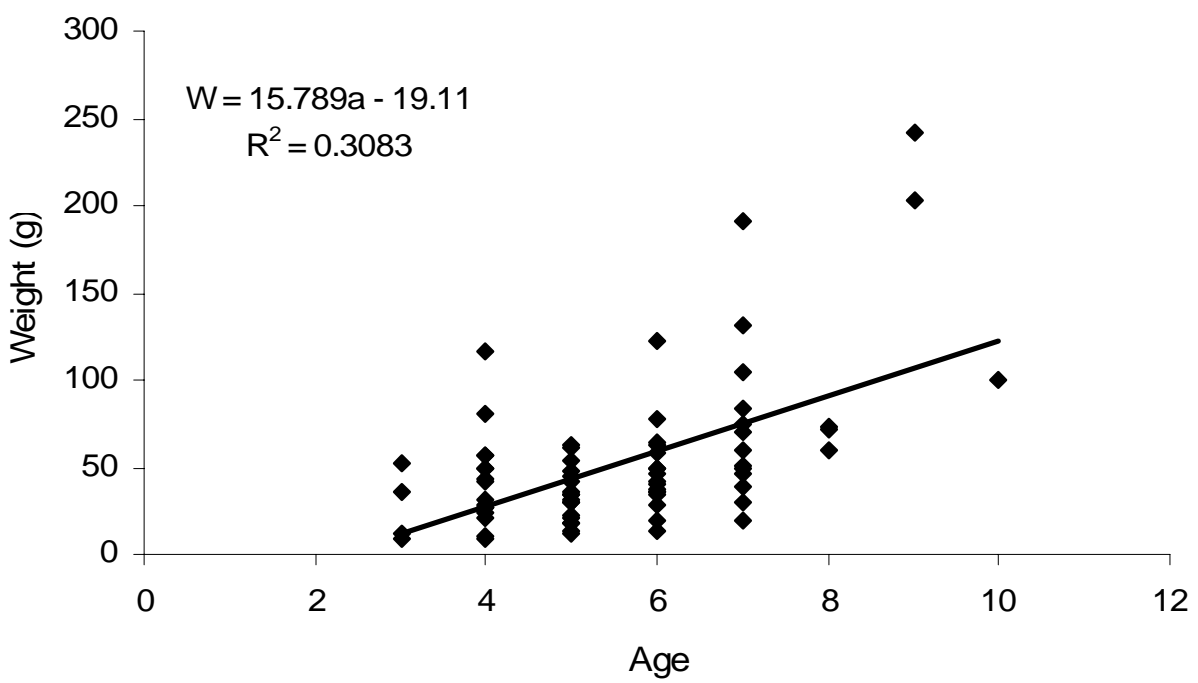

Figure 3. Age-length (A) and age-weight (B) relationships of American eels from the Millville Dam eel ladder, Shenandoah River, West Virginia. 
A)

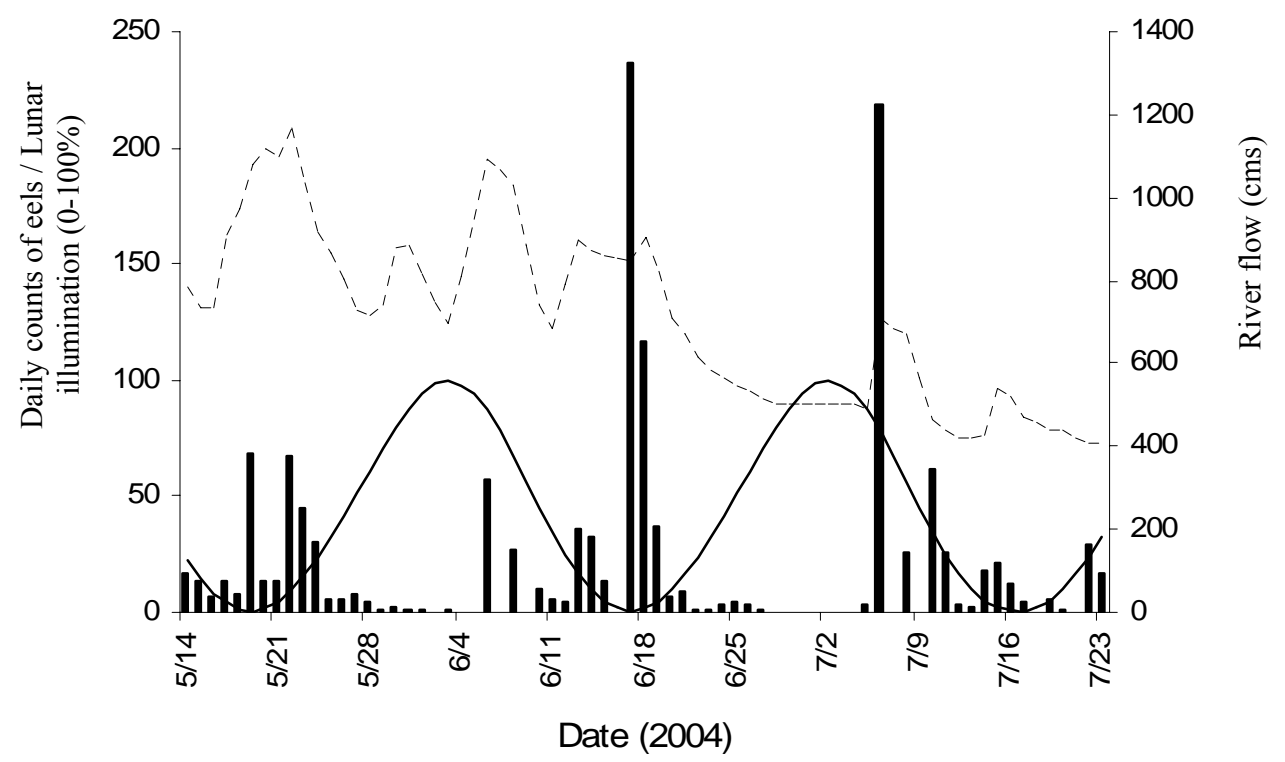

B)

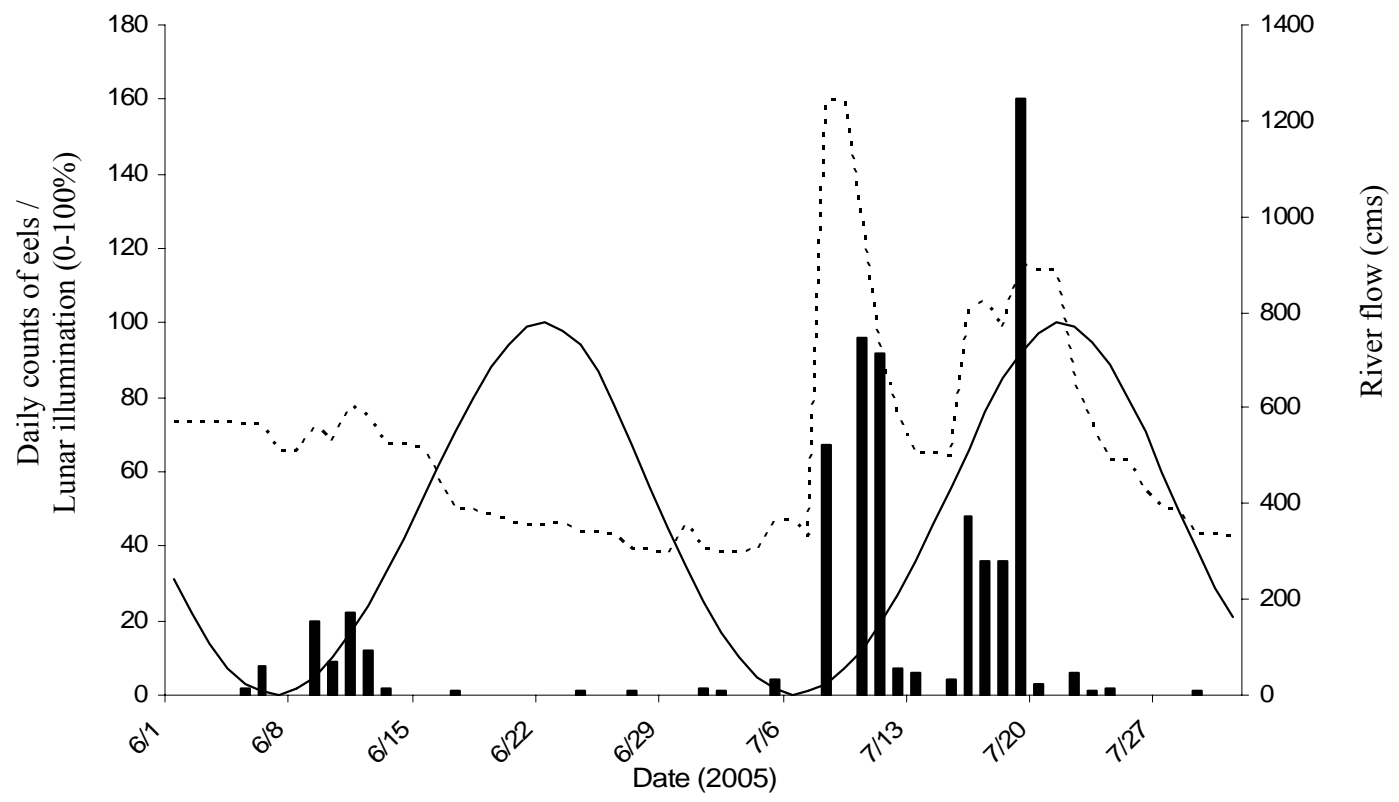

Figure 4. Daily counts of eels (bars) at the Millville Dam eel ladder and associated environmental variables lunar illumination (solid line) and river flow( dashed line) during two sampling periods; (A) May 14-July 23, 2004 and (B) June 1-July 31, 2005. 


\section{APPENDIX}

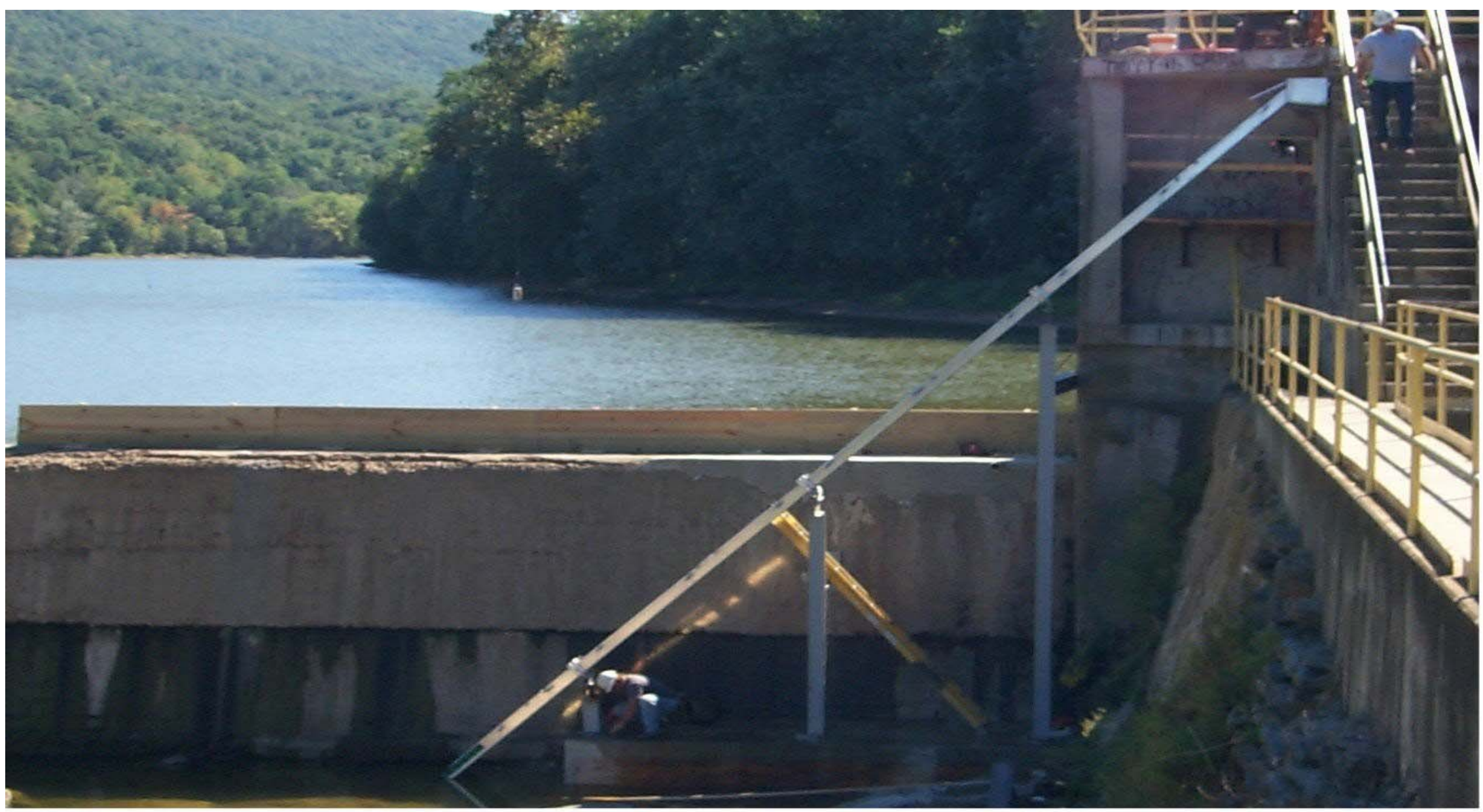

Appendix 1. Millville Dam eel ladder (design by Milieu, Inc. Canada). 

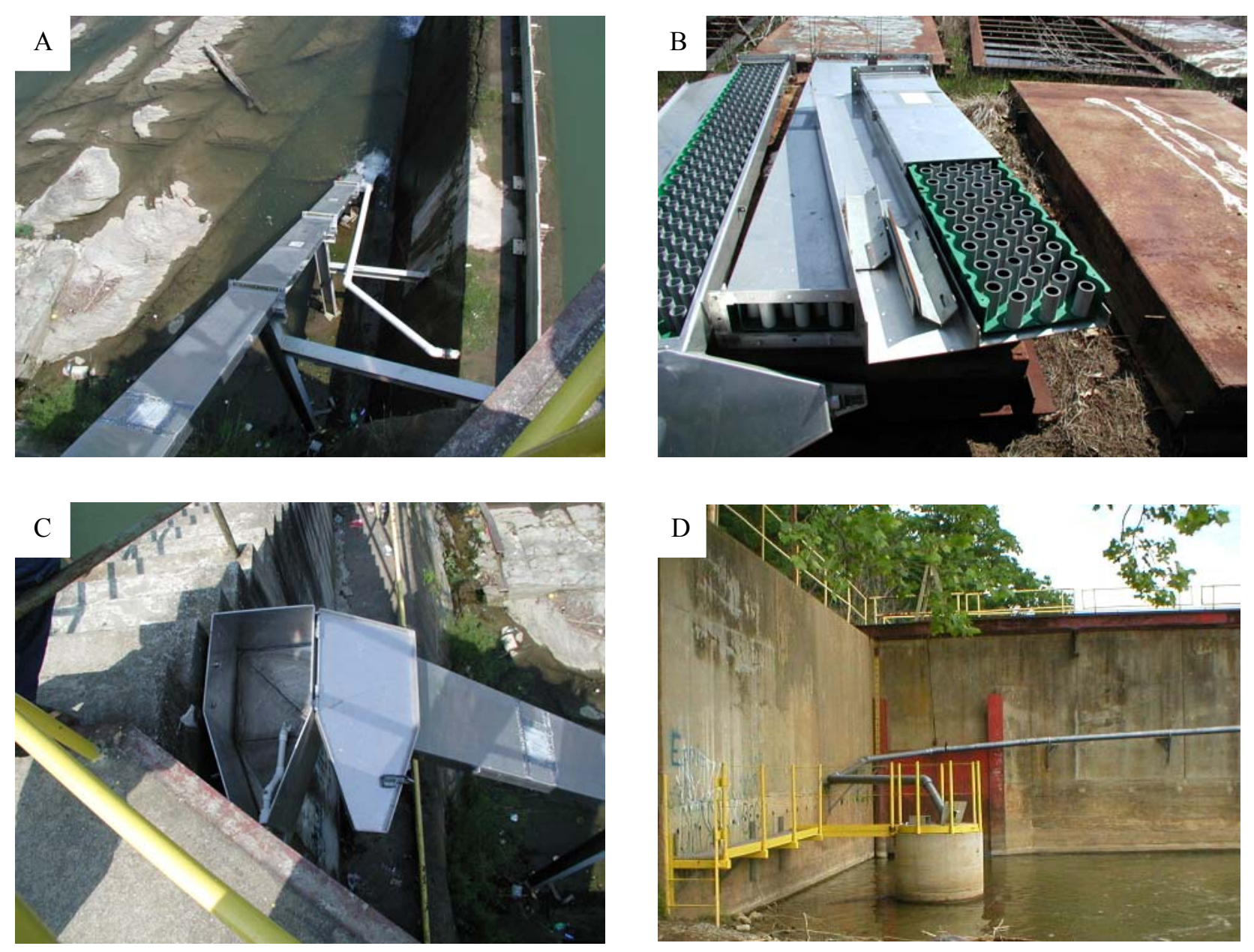

Appendix 2. Design specifications (A) flashboard placement and attraction flow, (B) internal design, (C) source of facilitation flow, and (D) upstream collection tank (housing the net system). 